\title{
Fast Profits: Investor Sentiment and Stock Returns during Ramadan*
}

\author{
Jedrzej Bialkowski**, Ahmad Etebari***, Tomasz Piotr Wisniewski****
}

\begin{abstract}
Observed by more than 1.5 billion Muslims, Ramadan is one of the most celebrated religious rituals in the world. We investigate stock returns during Ramadan for 14 predominantly Muslim countries over the years 1989-2007. The results show that stock returns during Ramadan are almost nine times higher and less volatile than during the rest of the year. No discernible difference in trading volume is recorded. We find these results consistent with a notion that Ramadan positively affects investor psychology, as it promotes feelings of solidarity and social identity among Muslims world-wide, leading to optimistic beliefs that extend to investment decisions.
\end{abstract}

JEL Classifications: G12, G14

Keywords: Ramadan Effect, Behavioral Finance, Market Efficiency, Religion

\footnotetext{
The authors would like to thank the Institute of Finance Professionals New Zealand Inc. for awarding this study the best paper prize in the investment category and MSCI Barra for providing useful data. The paper has been benefited from the comments of Warwick Anderson, Henk Berkman, Magdalena Bialkowska, Glenn Boyle, Stephen Ciccone, Eric Crampton, Timothy Crack, Mehrun Etebari, Aaron Gilbert, Robin Grieves, Ben Jacobsen, Jayant Kale, Brendan Lambe, Warren McNoe, Philip Meguire, Debra and Bob Reed, participants of the $14^{\text {th }}$ New Zealand Finance Colloquium, the $2^{\text {nd }}$ Finance and Corporate Governance Conference at the La Trobe University, the 2010 Annual Meeting of the Academy of Behavioral Finance \& Economics, and seminar participants at the University of New Hampshire, University of Otago, University of Canterbury, Queensland University of Technology and the European University Viadrina. The authors retain the sole responsibility for all remaining errors. An earlier version of this paper has been circulated under the title "Piety and Profits: Stock Market Anomaly during the Muslim Holy Month".

**: Jedrzej Bialkowski, Department of Economics and Finance, College of Business and Economics, University of Canterbury, Christchurch, New Zealand; email: jedrzej.bialkowski@canterbury.ac.nz; tel: 6499215401

***: Corresponding author. Ahmad Etebari, Department of Accounting and Finance, Whittemore School of Business and Economics, University of New Hampshire, Durham, NH, USA; email: ahmad.etebari@unh.edu; tel: 16038623359 ****: Tomasz Piotr Wisniewski, School of Management, University of Leicester, Leicester, England; email: tpw5@leicester.ac.uk; tel: 44 (0) 1162525515
} 


\title{
Fast Profits: Investor Sentiment and Stock Returns during Ramadan
}

\begin{abstract}
Observed by more than 1.5 billion Muslims, Ramadan is one of the most celebrated religious rituals in the world. We investigate stock returns during Ramadan for 14 predominantly Muslim countries over the years 1989-2007. The results show that stock returns during Ramadan are almost nine times higher and less volatile than during the rest of the year. No discernible difference in trading volume is recorded. We find these results consistent with a notion that Ramadan positively affects investor psychology, as it promotes feelings of solidarity and social identity among Muslims world-wide, leading to optimistic beliefs that extend to investment decisions.
\end{abstract}

JEL Classifications: G12, G14

Keywords: Ramadan Effect, Behavioral Finance, Market Efficiency, Religion 
A growing body of recent research shows that security returns respond to variables related to factors such as the weather, biorhythms, beliefs, and social identity. ${ }^{1}$ For instance, Hirshleifer and Shumway (2003) find that daily stock returns are significantly correlated with sunshine. Dowling and Lucey (2005) and Kamstra et al. (2000) present international evidence that seasonal variations in biorhythms and disruptions in sleep caused by changing to and from daylight saving time affect stock returns. Finally, Edmans et al. (2007) investigate the impact of international soccer results and find a significant market decline after losses by national soccer teams in international competitions.

These studies are motivated by a set of recent theories that focus on the effects of emotions and feelings on people's judgments and decision making. ${ }^{2}$ For example, Loewenstein et al.'s (2001) "risk-as-feelings" theory posits that people's feelings and emotions often influence their decisions, especially when such decisions involve risk and uncertainty. According to this theory both emotional reactions and cognitive evaluations guide reasoning and decision making, but when they diverge, emotional reactions often dominate behavior and influence the eventual decision (Simon, 1967; Lowenstein et al., 2001). In line with the findings that people in good moods tend to be more optimistic in their judgments than those in bad moods (Wright and Bower, 1992), these studies demonstrate that market prices can be influenced by changes in investor mood even when the underlying events are economically neutral from a direct cost-benefit perspective.

In this paper we examine whether a religious practice can, through its influence on investors' psychology, affect the behavior of the market. The important role played by religion has been highlighted in several earlier studies. Weber (1905) argued that Protestantism fueled the

\footnotetext{
${ }^{1}$ For a comprehensive review of the theory and evidence on this line of research, see Shiller (2000), Hirshleifer (2001), and Lucey and Dowling (2005).

2 The impact of investors' mood on their actions is of great interest to researchers in Behavioral Finance. The survey by Subrahmanyam (2007) reviews the developments in this field over the past two decades.
} 
development of early capitalism. Stulz and Williamson (2003) documented empirically that religion has the power to explain the cross-country variation in creditor rights and the level of enforcement. The existing literature also acknowledges that religiosity and social norms can have some bearing on investment decisions of institutions such as pension plans and corporate decision-making in general (see Hilary and Hui, 2009; Hong and Kacperczyk, 2009). We endeavor to add to the existing body of knowledge by focusing on the stock markets in countries where religion is an integral part of everyday life and determines much of the interaction within the society. Specifically, we examine the stock market effects of Ramadan fasting for nations where the majority of the population are adherents of Islam.

Observed by more than 1.5 billion Muslims around the world, the Ramadan fasting ("Swam") is one of the most celebrated religious rituals in the world. The significance of Ramadan is clearly stated in the holy Qur'an: "Ramadan is the month in which the Qur'an was revealed as guidance and clarification to humankind, and a distinction between right and wrong. Thus, whosoever among you witnesses the month should fast it."(Qur'an 2: 185) During Ramadan, with a few exceptions, Muslim adults fast each day from before dawn to the onset of night ("iftar") for roughly 11-19 hours, depending on the season in which Ramadan falls. The fast involves abstinence from eating, drinking and other sensual pleasures, as well as strict control of bodily compulsions, instincts, moods and desires of physical forms. Ramadan is a time of reflection, self-reformation, worshiping Allah, giving, spiritual cleansing and enlightenment (Qur'an 51:21; 2:183). During the holy month Muslims are urged to pursue "halal" (good deed) activities by forgetting past differences, forgiving, renewing both human and spiritual relationships and abstaining from "haram" (prohibited) activities. The ultimate goal of Ramadan is to make the individual become a more humane, considerate and responsible member of society. 
In practice, Ramadan is observed passionately and enthusiastically throughout the Muslim world. During the holy month people become more socially and spiritually oriented. They fast, perform more rituals, read and listen to recitations from the Qur'an, and show greater compassion for society's underprivileged members. ${ }^{3}$ Businesses operate as usual, though they tend to reduce or alter work hours in order for people to perform prayers and consume the evening "iftar" meal. Financial markets and banks also alter work hours in observance of Ramadan. Shops and markets re-open and stay open for a good part of the night. During the evening hours, people throng the streets in moods that are festive and communal. They shop, dine, and spend time with family and friends.

As a fundamental, shared experience, Ramadan brings about a greater solidarity and cooperation among Muslims throughout the world. A major contributor to this effect is the greater social support provided within the community and also the closer relationship an individual Muslim establishes with Allah, which in itself is a critical form of social relation. As indicated by research in positive psychology, religion provides a valuable form of social support, encourages optimistic beliefs, and contributes to the believers' happiness (Beit-Hallahmi and Argyle, 1997). The collective enthusiasm derived from Ramadan leads to a heightened sense of social identity and greater satisfaction with life for Muslims around the world. This satisfaction, in turn, may conceivably lead to optimistic beliefs that extend to the investment decisions of the followers.

The process of Ramadan-type fasting itself can substantially benefit the health of the devotee. As mentioned in the Qur'an and also supported by clinical research, fasting promotes both the physical and mental well-being of most practicing Muslims (Böck et al, 1978; Perk et al., 2001; Saleh et al., 2005). Clinical research shows that the Ramadan fasting generally makes people less tense

\footnotetext{
${ }^{3}$ Numerous sources report that during Ramadan the spirit of giving is at an all time high. For example, see Safaa Abdoun, "The Spirit of Giving during Ramadan," September 19, 2008, Daily News, Egypt.
} 
and anxious (Daradkeh, 1992) and that it may also induce mild states of euphoria (Knerr and Pearl, 2008). We will discuss this evidence further in the next section of the paper.

We postulate that the euphoria derived from Ramadan could influence investor behavior in Islamic markets. We hypothesize that the upbeat mood during Ramadan leads to positive investor sentiment and has a positive valuation effect on equity markets in Islamic countries. Mood aside, the demand for equities may also increase as a result of the favorable health status enjoyed by the local Muslim investors. Rosen and Wu (2004) report that households in good health are inclined to hold a greater share of risky assets in their portfolios. Similarly, Edwards (2008) finds that retired people perceive significant risks associated with future health shocks and that these perceptions lead to a continued reduction in financial risk taking. In light of the foregoing discussion, we would expect the Ramadan period to coincide with notable increases in the prices of risky securities.

This study is a comprehensive examination of stock returns for a broad sample of 129 Ramadan months for 14 predominantly Muslim countries over the period running from 1989 to 2007. The results show that during Ramadan stock returns are on average much higher and less volatile compared to the rest of the year. The results also show that there is no discernible change in trading volume between Ramadan and other months of the Islamic lunar year. We find these results consistent with our prior expectation that Ramadan has a positive impact on the mood and hence on investors' sentiment.

We show that the results are unrelated to well-documented calendar anomalies such as the "January effect" or the "Turn-of-the-Week effect". Ramadan is the ninth month of the Islamic lunar calendar, a calendar that contains twelve months each starting with the sighting of a new moon. As explained later in this paper, the Islamic lunar year is approximately 11 days shorter than the Gregorian solar year. So, over time, Ramadan does not coincide systematically with a fixed day or 
season in the Gregorian calendar. We specifically control for the presence of any Monday, January or Halloween effects, but we find that none of these explain the results.

The remainder of this paper is organized as follows: Section I presents a discussion of the literature on the health benefits resulting from fasting and the evidence of the market effects of religious festivities. Section II outlines the data set and the data collection procedures. Section III discusses the results, while Section IV examines the robustness of these results. The last section concludes the paper.

\section{Related Studies of Fasting and Religious Festivities}

This section consists of two parts. The first part is a review of the clinical research into the health effects of fasting. In the second part, we review the evidence on the effects of Ramadan on the Islamic stock markets, as well as the effects of other holidays on markets elsewhere around the world.

\section{A. The Ramadan Fast and Its Health Benefits}

Ramadan is one of the holiest months of the Islamic calendar. Fasting ("Swam") is the most prominent event in Ramadan. Along with the testimony of faith ("Shahadat"), ritual prayer ("Salat"), almsgiving ("Zakat"), and a once-in-a-lifetime pilgrimage to Makkah ("Hajj”), fasting during Ramadan is one of the five pillars of Islam. ${ }^{4}$ As an expression of penance for sins and gratitude for the blessings enjoyed during the past year, an observant Muslim fasts during the holy month (Wagtendonk, 1968). Throughout this period, a follower of Islam has to abstain from ingesting food and liquids between sunrise and sunset. With a "Suhoor" pre-dawn meal and an "iftar" supper the consumption becomes entirely nocturnal.

\footnotetext{
${ }^{4}$ These five practices are essential to the Sunni sect. Shi'ite Muslims also subscribe to more ritual practices that overlap with the five Pillars.
} 
The sick, the elderly, travelers and women who are pregnant, breastfeeding or menstruating are exempt. They can make up for the missed days of fasting at a later date. Should it prove impossible due to an ongoing or chronic illness, they can pay a compensation called "Fidyah", which is usually equivalent to feeding a hungry person who is in financial difficulties. Others who are exempt include young children and the insane. With the notable exception of the aforementioned groups, Ramadan-type fasting ${ }^{5}$ can have a wide range of beneficial effects for health.

Although in the initial stage of fasting individuals may experience a feeling of discomfort, this symptom typically abates after the second day of the fast. Proponents of natural medicine argue that it arises as a by-product of the detoxification process, in which the toxins previously stored in fatty tissues are expelled from the body (Fuhrman, 1998). Fasting also provides a respite to the digestive tract and allows for the elimination of superfluous tissue. A number of clinical studies have reported a reduction of body weight and waist circumference in subjects under controlled fasting conditions (Böck et al. 1978; Perk et al., 2001; Saleh et al., 2005; Bouhlel et al., 2008). The ramifications of this observation for the cardiovascular system and oxygenation are immense. Moreover, Saleh et al. (2005) report a significant reduction in total cholesterol and LDL-cholesterol in male subjects, as well as a decrease in the atherogenic index for the whole sample during the fast of Ramadan.

Not only can the periodic food deprivation alter the state of consciousness, but it can also promote mental wellbeing. Having investigated the clinical effects of fasting therapy on a large sample of patients with psychosomatic and mental diseases, Yamamoto et al. (1979) conclude that it was efficacious in $87 \%$ of the cases. Symptoms of disorders such as conversion hysteria, depression, anxiety neurosis and hypochondriasis had been significantly alleviated by fasting. In a follow-up study, Yamamoto (1980) monitored the electrical activity of the brain in fasting subjects by placing

\footnotetext{
5 The term "fasting", as used in this paper, describes a fasting-refeeding cycle with two meals being consumed daily. Under no circumstances do we try to claim that total abstention from food leads to health improvements in the longrun, nor that it should be recommended as a treatment for serious medical conditions.
} 
electrodes on their scalp. This electroencephalographical (EEG) analysis revealed that fasting increases the percent energy of alpha waves, while simultaneously reducing the percent energy of beta. The observed fall in the frequency of rhythmic activity indicated that patients became less anxious and tense. In view of these findings, it is perhaps unsurprising that the number of reported suicide attempts drops during the month of Ramadan (Daradkeh, 1992).

Many of those who fast tend to experience mild states of euphoria. As the human body enters into a fasting mode, its stores of glucose are progressively used up. Ketone bodies produced in the liver start to supplant glucose as an energy source for the brain (Knerr and Pearl, 2008). Interestingly, one of the ketone bodies, $\beta$-hydroxybutyrate, is an isomer of GHB ( $\gamma$ hydroxybutyrate), which is known to the medical profession as an antidepressant and is also used illegally by some people as a mood-enhancing drug. Noting the structural similarities between the abovementioned ketone body and GHB, Brown (2007) hypothesizes that they may have comparable effects on the brain, which would explain the diet-induced euphoria.

\section{B. Previous Studies of Religious Festivities}

Numerous studies have examined security returns for the presence of recurring seasonal patterns in the Gregorian calendar. Among other findings, these studies report persistent anomalous returns around the turn of the week, the turn of the month and the turn of the year (for example, see Lakonishok and Schmidt, 1988). However, there are only a few studies that investigate the market effects of non-secular festivities such as Ramadan. In this section we present a brief overview of the more relevant research.

Seyyed et al. (2005) examines the behavior of the Saudi Arabian stock market in Ramadan during the period of 1985-2000. They find no significant change in mean return but a noticeable decline in volatility. Ours is a more comprehensive study, which includes a cross-section of countries 
observed over a relatively long period. While our results for Saudi Arabia are not dissimilar to those of Seyyed et al. (2005), we document that most of the other Islamic markets have historically experienced large stock price increases during the holy month. Importantly, we are the first to document robustly the existence of this stock market anomaly. Finally, our paper builds on the results already established in different fields of science such as medicine, psychology and sociology. The findings presented here, therefore, cannot be subject to the common data snooping critique that may be relevant in the context of other studies (see Crack, 1999; Subrahmanyam, 2007).

A related stream of research is the literature on the effects of religious holidays and other national festivities. Lakonishok and Schmidt (1988), as well as Ariel (1990) and Cadsby and Ratner (1992), report that independently of other calendar-based anomalies stock returns tend to increase prior to public holidays during which markets are closed. These holidays include Christmas and Good Friday, two important religious holidays.

In a similar study, Frieder and Subrahmanyam (2004) test the effect of Jewish sentiment on the U.S. equity market by examining return and volume around major Jewish High Holy Days on which the stock market remains open. This study finds that stock returns are significantly up on Rosh HaShanah (a festive day, commonly known as the Jewish New Year) and the prior two days but significantly down on Yom Kippur (a somber day) and the day after. For both Holy Days, Frieder and Subrahmanyam (2004) report a decline in the volume of trading. ${ }^{6}$ Frieder and Subrahmanyam (2004) attribute their results to the sentiment of Jewish investors and their trades around these holidays.

Ramadan is an uplifting holiday for Muslims as is Rosh HaShanah for Jews. Like Rosh HaShanah, Ramadan is an event capable of influencing the moods and decisions of the adherents. During Ramadan participating Muslims seek a closer relationship with Allah and follow a set of

\footnotetext{
${ }^{6}$ Frieder and Subrahmanyam (2004) also analyze market data around the Christian Feast Day of St. Patrick and find results similar to those they report for Rosh HaShanah.
} 
prescribed standards of behavior intended to make them become better Muslims and more responsible members of society, which can improve their feelings of self-worth. Thus, we expect Ramadan to produce an upbeat sentiment, overconfidence and a greater willingness to accept risk by Muslim investors.

\section{Data}

Ramadan is the ninth month in the Islamic (or "Hijri") calendar, which is based on the motion of the moon. Obtaining historical information on the duration of Ramadan is a demanding task, as the holy month does not have a fixed date in the Gregorian calendar. The Islamic calendar is used mainly for observance of religious holidays and functions, whereas the Gregorian calendar is used for business and government. The 12 months derived from the lunar cycle are separated by the appearance of the new moon and the number of days in a month averages between 29 to 30 days, making the Islamic year approximately 11 days shorter than the Gregorian one. In this paper the allimportant event dates are not approximated, but rather derived from precise astronomical calculations.

If a new moon sighting occurs before sunset, Ramadan will start the following day. The subsequent new moon breaks the fast and the celebrations related to the "Eid al-Fitr" festival follow. The technical difficulty that arises at this stage is that both the visibility of the moon and the sunset time are dependent not only on the date, but also on the geographical location of the observer. In performing the calculations, we have explicitly assumed that the celestial bodies are observed from the perspective of individuals residing in the capital cities of the countries covered in our study. The latitudes and longitudes of these cities were obtained from the National GeospatialIntelligence Agency. These coordinates were then imputed into an applet provided courtesy of Astronomical Applications Department at the U.S. Naval Observatory in order to obtain 
information on the lunar phases and sunset times at each location. Implementation of this procedure allowed the determination of the exact starting and ending dates of the holy month.

Our sample includes countries for which stock market index data were available from Morgan Stanley Capital International (MSCI) in Datastream and in which the proportion of population professing Muslim faith exceeded 50\%. The data on population and religious fractionalization was sourced from the Central Intelligence Agency (CIA)'s World Factbook (2009). Data on countries for which the CIA did not record the exact proportion of Muslims in the society was extracted from the Association of Religion Data Archives. As can be seen from Table 1, the final sample comprises 14 countries inhabited by nearly 695 million people. For each country, the date on which daily observations on the MSCI index first became available determines the number of events. It needs to be mentioned that the event study analysis performed in the next section requires at least 200 observations before the first Ramadan starting date, so that a benchmark model for the returns can be estimated. Guided by these considerations, we arrive at a sample of 129 events.

[Insert Table 1 about here]

Although the Muslim community is dominant in the societies considered, on average accounting for $90.9 \%$ of the total population, any foreign participation in the stock markets could potentially diminish the importance of this figure in the context of our study. In order to gauge the extent of non-Muslim foreign ownership, we have consulted the OSIRIS database published by Bureau van Dijk. The direct ownership data was extracted by manually matching the SEDOL codes of all of the MSCI index constituent companies appearing on the MSCI Frontier and Emerging 
Markets lists at the end of our sample period with the OSIRIS entries. To ensure that the matching procedure is accurate, the codes were cross-checked with the Datastream database. In our calculations we have assumed that any investor residing/headquartered outside the 14 countries listed in Table 1 is a non-Muslim. For the sample as a whole, the capitalization-weighted average of non-Muslim foreign direct ownership computed across companies included in MSCI country indices is as low as $9.1 \%$. Consequently, it may be argued that the followers of Islam hold a controlling stake in the local stock markets and that their investment decisions play a key role in the price formation process.

\section{Results}

Figure 1 plots the average returns during the holy month and the rest of the year. For the purposes of comparison, these continuously compounded returns were denominated in US dollars and annualized. Visual inspection of the bar chart reveals that the differences in means across markets are quite striking, with 11 out of 14 countries having higher average returns during Ramadan. In aggregate, the mean annualized return realized by investors during the holy month was $38.09 \%$, compared to a rather modest gain of $4.32 \%$ throughout the rest of the year. The results reported for the three countries that did not experience this apparent Ramadan effect have to be interpreted with great caution. The inferences for both Bahrain and Saudi Arabia are based on a limited number of observations, whereas much of the hardship experienced by Indonesia during the Asian Crisis coincided with Ramadan. Overall, however, this preliminary data analysis reveals a rather curious anomaly and underscores the need for further examination. 
[Insert Figure 1 about here]

To this end, two versions of an event study analysis were performed. In the first version, the benchmark returns were generated by a constant-mean-return model, whereas the second event study considers the observed returns in relation to the predictions of the market model. ${ }^{7}$ A valueweighted MSCI World Index comprising 23 industrialized countries was taken as a proxy for the market portfolio. None of the countries used to make up this index meet our definition of being predominantly Muslim, which implies that the selected benchmark remains reasonably eventindependent. In order to ensure that the estimation window does not include the preceding year's Ramadan, its length was restricted to 200 trading days. The abnormal returns were defined conventionally as the returns in excess of what the investor would expect in absence of the event. These returns were subsequently averaged over all events and summed over time to form cumulative abnormal returns (CARs).

The statistical significance of CARs was verified using a parametric $t$-test similar to that of Kothari and Warner (2007). Notably, this testing approach disposes of the homoscedasticity assumption and is able to accommodate event-induced changes in volatility. The test statistic can be expressed as:

$$
t\left(C A R\left(n_{1}, n_{2}\right)\right)=\frac{C A R\left(n_{1}, n_{2}\right)}{\sigma(A R) \times \sqrt{n_{2}-n_{1}+1}}
$$

where $n_{1}$ and $n_{2}$ are, respectively, the beginning and end dates of a given event window and $\sigma(A R)$ is the standard deviation of mean abnormal returns computed in the time-series dimension over the

\footnotetext{
${ }^{7}$ A detailed description of both approaches can be found in Campbell, Lo and MacKinlay (1997).
} 
$\left(n_{1}, n_{2}\right)$ period. Furthermore, the evidence is supplemented by the results of a sign test, which does not make any assumptions regarding the distribution of underlying returns. Following Banerjee and Eckard (2001), we define the ₹-statistic as follows:

$$
z=\frac{p-0.5}{\sqrt{p(1-p) / N}}
$$

where $p$ is the fraction of positive CARs in our sample and $N$ is the number of events.

[Insert Table 2 about here]

Depending on the motion of the moon, the holy month of Ramadan lasts either 29 or 30 days. This translates into 21-22 days of trading, or equivalently into a $(0,20)$ or $(0,21)$ event window. According to the results reported in Table 2, the cumulative abnormal returns during the considered period are strongly statistically significant, regardless of the testing method used. The two different methodological approaches produce estimates of CARs within the $2.48 \%-3.11 \%$ range and these estimates can increase to as much as $4.99 \%$ once the event window is extended to incorporate days surrounding Ramadan.

\section{[Insert Figure 2 about here]}

The intriguing pattern revealed by the plot of CARs in Figure 2 warrants further elaboration. First, the abnormal growth in stock prices during the first 5 days of the holy month is negligible. This is perhaps not entirely surprising, as a fraction of people may experience some discomfort in the initial stages of fasting arising as a by-product of the detoxification process and the changed dietary regimen. These symptoms, however, subside quickly and the subsequent increased 
production of ketone bodies will improve the mood of a representative investor. What also becomes apparent when examining Figure 2 is that stock prices continue to rise for a number of days after the fast is complete. To a certain extent this may be a reflection of the sense of accomplishment that comes with achieving spiritually meaningful objectives, a sense that permeates the whole society. These positive feelings as well as the communal spirit are likely to be reinforced by the three-daylong "Eid al-Fitr" festival commencing upon the completion of the Ramadan fast. Muslims who partake in the festivities tend to spend a greater portion of their time in a circle of family and friends, and on religious services that can reinforce an optimistic view of the world.

An issue that may arise when evaluating the statistical significance within a standard eventstudy framework is the contemporaneous correlation of abnormal returns in the cross-sectional dimension. Since the periods of the holy month tend to partially overlap across countries, one could suspect that such correlation may be present in our data. A number of authors have argued that the problem of event clustering can be addressed by aggregating returns into a portfolio and regressing the resultant portfolio returns against an event dummy variable (Izman, 1978; Blinder, 1985, 1998; Bartholdy et al., 2004). Although this approach has the potential to remedy the complications arising from cross-correlation of returns, it may also result in a reduction in power (Bernard, 1987).

The regression reported below links the returns on an equally-weighted portfolio constructed from the stock market indices of the 14 predominantly Muslim nations in our sample with the returns on the MSCI World Index and a Ramadan dummy variable. Since the dates of the holy month differ slightly across countries, the dummy starts recording a value of one with the first commencement of Ramadan and reverts back to zero when the holy month is ended in all nations. The $t$-statistics based on the White (1980) corrected standard errors are given in parentheses. 


$$
\begin{array}{r}
\text { Return_Portfolio }_{t}=0.01+0.11 \text { Ramadan }_{t}+0.22 \text { Return }_{-} \text {World }_{t}+\varepsilon_{t} \\
(1.09)(3.15)
\end{array}
$$

Adj. $R^{2}=4.04 \%$

The $p$-value associated with the null hypothesis that the coefficient on Ramadan is equal to zero is as low as 0.0016 , collaborating our earlier conclusions.

An alternative methodology capable of dealing with the issue of overlapping events is a variant of the calendar-time portfolio approach advocated by Jaffe (1974), Fama (1998) and Mitchell and Stafford (2000). It is implemented here by applying the event study analysis to the equallyweighted portfolio constructed from national indices. Since the estimate of portfolio variance automatically takes account of any potential cross-country dependence, the parametric test statistic for CARs is unlikely to be overstated (Mitchell and Stafford (2000)). However, the obvious deficiency of this approach is the reduction in sample size from 129 to 19 . Notwithstanding the smaller number of observations, we find that the CARs retain their statistical significance in this model setting. The $t$-statistics for the $(0,20)$ event window are 3.02 for the market model-adjusted cumulative abnormal returns and 3.43 for the constant-mean-model. Both of the corresponding $p$ values fall comfortably below the $1 \%$ level. This confirms that the seasonal effect tested in this paper is unlikely to be a mere by-product of the specific testing methodology adopted.

Although the cumulative abnormal returns are both statistically and economically significant, one has to ensure that they are not merely a compensation for increased risk during the Ramadan period. In order to detect any potential changes in the riskiness of the stock markets an examination of return volatility was undertaken. Figure 3 depicts a geometric average of annualized standard deviations calculated across all of the 129 events. The estimation of volatilities follows a movingwindow approach, in the sense that for any given day in the event window the standard deviations 
were measured over the previous 20 trading days. This means that values recorded for days 19-21 are representative of the index volatility observed during the holy month. Quite remarkably, these days coincide with a notable dip on the graph. One can consequently conclude that the observed "Ramadan effect" cannot be easily rationalized within the market efficiency framework and ought to be regarded as anomalous.

[Insert Figure 3 about here]

Table 3 presents additional results regarding the arithmetic averages of unconditional standard deviations disaggregated by country. With the exception of Turkey, all of the countries experienced a drop in index volatility during Ramadan. The statistical significance of this phenomenon was tested using a Wilcoxon signed-ranks test (nonparametric), which takes into account both the direction and the relative magnitude of changes (Daniel, 1978; Kanji, 1993). Under the null hypothesis of constant variance the test statistic follows a standard normal distribution. The null hypothesis is, however, convincingly rejected at the conventional significance levels. One could explain this result by referring to the literature on human psychology. Ellison et al. (2009) have demonstrated empirically that religious beliefs and high degrees of social integration positively influence individuals' feeling of tranquility. It is therefore plausible that as many investors reach the state of inner peace and calmness, the behavior of stock prices will change to reflect this.

[Insert Table 3 about here] 
Finally, it needs to be noted that previous work has reported a strong negative relationship between liquidity and expected excess returns (see Amihud and Mendelson (1986, 1991)). Consequently, further analysis is needed to assess whether the abnormal returns observed during the month of Ramadan are not a manifestation of the illiquidity premium. As described by Amihud (2002), liquidity is a rather elusive concept and a wide range of proxies can be used to gauge it. Guided primarily by data availability considerations, we have adopted a liquidity measure defined as the total value of trading volume divided by the total market capitalization. This definition parallels that employed by Haugen and Baker (1996) and Bhattacharya and Daouk (2002).

In order to find the data required for the construction of the abovementioned turnover ratio, Datastream was searched for firm-level information. For a company to be included in our sample it had to be listed in one of the stock markets studied here and it had to have complete data on trading volume and capitalization throughout the entire sample period. The latter criterion ensured that the sample composition remained unaltered throughout the entire span of the analysis. In total, 364 companies were included and the calculation of the turnover ratio was based on their aggregate dollar-denominated daily trading volumes and market capitalizations. Figure 4, which plots the ratio relative to the event starting date, does not lend credence to an assertion that markets were drained of liquidity during the holy month. In fact, the average daily turnover is slightly higher in the $(0,20)$ event window compared to a pre-event window of equal length $(0.37 \%$ vs. $0.34 \%)$. As a result, changes in liquidity cannot be credibly propounded as an explanation of the Ramadan effect.

[Insert Figure 4 about here]

\section{Robustness Checks}


Although the prevalent view among Muslims is that the holy month starts when the birth of a new moon is observed locally, a small minority focuses on the visibility of the crescent from the perspective of Makkah and fasts accordingly. As the birthplace of Prophet Muhammad (PBUH) and the city in which Islam was proclaimed, Makkah plays an important role in the Muslim faith. The Islamic Society of North America, for instance, disseminates information about Ramadan dates, announced by the Fiqh Council of North America, based solely on the Saudi lunar cycle. To verify the robustness of the results, the event-study analysis was repeated under the assumption that the dates of the holy month in all countries coincide with the sighting of the new moon in Makkah. The cumulative abnormal returns reported in Table 4 retain their statistical significance and deviate only by a couple of basis points from the estimates of our baseline model. Consequently, a change in the interpretation of the sighting does not alter the main conclusions of this paper.

[Insert Table 4 about here]

Fasting can become particularly demanding on long summer days when the break between the meals is protracted and the risk of dehydration is higher. One could therefore speculate that such conditions would be less conducive to good mood. This contention was investigated by looking at the relationship between the cumulative abnormal returns and the length of the day from sunrise to sunset. The day length was measured in minutes on Ramadan's first day of trading. Table 5 presents the results of the correlation analysis that followed. Even though the correlation coefficients have the expected sign, they are negligible and statistically insignificant. These findings attest to the fact that the Ramadan-induced abnormal returns are relatively insensitive to the changes in duration of the within-day fasting period. 
[Insert Table 5 about here]

Although the MSCI indices are available for a large cross-section of countries, one of the concerns which can be raised is that there is a limited number of observations for Saudi Arabia, a country crucial to our investigation. In an attempt to circumvent this data issue, we have downloaded market capitalization-weighted indices compiled by Standard \& Poor's from Datastream for all countries that had daily series of sufficient length. ${ }^{8}$ This alternative dataset comprised 8 national stock markets and 59 Ramadan events (13 events for Jordan, 12 for Pakistan, 11 for Saudi Arabia, 7 for Bahrain and Oman, and 3 for United Arab Emirates, Qatar and Kuwait). Figure 5 depicts the annualized US dollar-denominated stock market returns during the holy month and the rest of the year. The evidence of the Ramadan effect is compelling and observed in all of the sample countries. Inclusion of additional observations for Bahrain and Saudi Arabia strengthened the results in favor of the anomaly. Overall, the annualized returns averaged $40.77 \%$ during the holy month compared to $11.87 \%$ during all of the remaining lunar months. The null hypothesis of mean return equality was strongly rejected $(t$-statistic $=3.65)$, lending support to the conclusions of our paper.

[Insert Figure 5 about here]

\footnotetext{
${ }^{8}$ A series was considered to be of sufficient length if it spanned back at least to $01 / 01 / 2006$.
} 
Before it can be claimed that the Ramadan effect is an anomaly in its own right, it needs to be demonstrated that it is truly independent of other calendar effects reported in the literature. Among these, the turn-of-the-year seasonality has likely received the most attention from the academic community. The observation that the U.S. stock market returns are elevated in January was first made by Rozeff and Kinney (1976) and later confirmed in a study using an international sample by Gultekin and Gultekin (1983). Reinganum (1983) argued that this evidence is consistent with taxloss-selling, whereas Keim (1983) viewed it through the prism of the size effect. In what follows, we exclude all holy months commencing in January from our sample, thereby reducing the number of relevant events to 115. The plot presented in Panel A of Figure 6 confirms that our results remain robust even after the month of January was discarded. The annualized return during an average ninth month of the Muslim calendar, which did not start in January, is $30.38 \%$. This figure is significantly higher (at 5\% level) than the returns realized by investors throughout the rest of the year.

[Insert Figure 6 about here]

Another seasonality we focus on is what is commonly labeled the "Halloween effect". Bouman and Jacobsen (2002) conclude that it is optimal for investors to pursue a "Sell in May and go away" strategy, staying in cash until the end of October and then investing in stocks, as the average stock returns during the November-April period are much higher compared to the other half-year. Consequently, the second sub-sample we construct comprises all months of Ramadan that did not start between November and April. This condition was met by 50 events and the findings are depicted in the Panel B of Figure 6. Accounting for the Halloween anomaly only 
strengthens our conclusions with regard to the existence of a Ramadan effect. In this case, the average annualized returns during the event period amounted to a staggering $51.78 \%$ (corresponding $t$-statistic $=4.44)$.

The seasonal patterns in stock returns were also controlled for in a multivariate framework. In addition to the January and Halloween anomalies, Table 6 considers the well-documented Monday effect (Cross, 1973; French, 1980; Gibons and Hess, 1981; Keim and Stambaugh, 1984). Panel A of the table reports the results of pooled OLS estimation, whereas Panel B employs a fixed effect panel approach. The latter methodology accommodates the time-invariant heterogeneity across countries and is relatively robust to any possible omitted variable biases (Chamberlain, 1978). The results reveal that the calendar anomalies observed in the more developed capital markets can also be documented for the counties in our sample. Most importantly, the Ramadan binary variable is statistically significant in all of the specifications and the impact of the Muslim holy month on the first moment of return distribution appears to be unrelated to changes in the value of world market portfolio.

[Insert Table 6 about here]

For our explanations to be plausible and consistent, it also needs to be shown that the effect induced by Ramadan is weaker in countries where the proportion of population adhering to the Islamic faith is smaller. In order to verify this hypothesis, we collected data on all 67 countries for which the MSCI indices were available in Datastream. These nations were subsequently divided into three subgroups according to the religious fractionalization of the society. Group A comprises the 
14 nations in which the fraction of Muslims in total population exceeded 50\%, Group B includes another 14 countries in which this fraction fell between 5\% and 50\%, and Group C consists of the 39 nations which did not meet the 5\% threshold. A portfolio was constructed for each of the groups by equally weighting the dollar-denominated returns on the national stock market indices.

These portfolio returns were then linked to the Ramadan zero-one dummy variable and additional controls using a Multivariate Regression Model. This methodological approach is similar to that used in Schipper and Thompson (1983), Blinder (1985, 1998), Cornett and Tehranian (1990) and Wagster (1996) and employs the seemingly unrelated regression (SUR) technique introduced by Zellner (1962) to estimate a system of equations. The results of the SUR estimation for our 3 country-groups are reported in Table 7 and appear to accord with the basic intuitive predictions. The effects of Ramadan materialize only when the society chooses to participate in this religious experience collectively. Unsurprisingly, the joint hypothesis that the coefficients on the Ramadan dummy in the regressions for groups B and C are equal to zero cannot be rejected.'

[Insert Table 7 about here]

We also investigate whether the anomaly has persisted over time. Had the effect been discovered by market participants prior to the end of our sample, they would have adjusted their trading strategies to take advantage of it. In doing so, they would have made the markets more efficient. Figure 7 presents market returns during two periods: 1989-2000 and 2001-2007. This split generates two sub-samples with comparable number of observations. The gap in annualized returns

\footnotetext{
${ }^{9}$ The relevant F-statistic is 1.01 for Panel A of Table $6(p$-value $=0.3628)$ and 0.51 for Panel B $(p$-value $=0.5996)$.
} 
between Ramadan and the rest of the year actually increased from $31.98 \%$ to $35.59 \%$ between the first and second intervals. Consequently, the results do not suggest that Islamic stock markets were becoming increasingly efficient over time.

[Insert Figure 7 about here]

Lastly, we analyze whether the effect described in this study arises from the fluctuations observed in the foreign exchange market. We operationalize this analysis by repeating the return calculations for MSCI indices, this time denominated in local currency, and contrasting the results with our initial findings. As expected, the conclusions change substantially in favor of the anomaly for Indonesia, where the occurrence of holy month coincided with the Asian crisis. On the other hand, the change of denomination eliminates the existence of the effect in the Tunisian stock market. Overall, the annualized difference in returns between the Ramadan and non-Ramadan periods increases from $33.77 \%$ when the returns are measured in US dollars to $35.66 \%$ when they are expressed in domestic currency terms. We thus conclude that the Ramadan effect is driven primarily by the changing values of stock prices, rather than the movements of exchange rates.

\section{Conclusions}

Motivated by the evidence from positive psychology showing that religion affects believers' mood, happiness and risk-taking attitude, we investigate the market effect of Ramadan, one of the 
most celebrated religious rituals in the world. Using daily equity return data for 14 predominantly Muslim countries over the years 1989-2007, we find evidence of a strong Ramadan effect. Specifically, over the holy month the mean annualized return is on average almost nine times greater than the mean return over the rest of the Islamic year (38.09\% vs. $4.32 \%)$. Data from different providers were examined and ten different testing approaches were used ${ }^{10}$, each time re-confirming the robustness of the anomaly. Despite these large returns, we find a significant decrease in volatility in all but one of the sample countries. These results imply a sharp shift in the investors' optimism. We check whether the effect is due to market liquidity, length of the daily fasting period, currency fluctuations and some well-known fixed calendar anomalies, notably the Monday, January and Halloween effects. None of these factors explain the results. Hence, we find the results anomalous and inconsistent with the notion of market efficiency.

We believe that the Ramadan effect documented in this paper can best be explained by a change in investor psychology. Ramadan is a religious month that affects almost every aspect of Muslims' lives. Besides fasting and prayers, Ramadan promotes heightened social awareness and a closer relationship with Allah and with other fellow Muslims around the world. As a fundamental shared experience, Ramadan brings about a sense of solidarity among Muslims, enhances their satisfaction with life and encourages optimistic beliefs. This optimism affects investor sentiment and decisions leading to the price run-ups we report in this paper.

Our baseline results have been derived from the analysis of stock indices (MSCI and S\&P) of 14 countries. Collectively, they reflect the decisions of many investors in the Muslim world. It would be interesting to further explore the Ramadan effect at the individual company or business sector

\footnotetext{
10 The statistical and econometric methods employed in this paper included: a simple test for equality of two mean returns, parametric $t$-test and non-parametric z-test in both constant-mean-adjusted and market-model-adjusted event study, portfolio regressions, portfolio-based event study, pooled OLS regressions, fixed effect panels, and SUR models.
} 
level. Some companies might operate more in line with the core tenets of Islam and might be more socially responsible than others. Such companies might benefit more from the behavioral biases of pious investors during Ramadan. Further evidence would help us better understand what drives the Ramadan effect and what the determinants imply for asset valuation. This understanding is important given the potential opportunities these mostly frontier markets provide to the investing public.

The implication of our findings for investors is obvious. Investors seeking fast profits in the Muslim world should try to profit from the fast, buying shares prior to the start of Ramadan and selling them at the end of the holy month or preferably immediately after Eid al-Fitr. Of course, there are transactions costs that one would need to take into account, but any such costs would appear to pale in comparison to the observed returns. Alternatively, investors could embark on a more passive strategy by delaying their sales until the end of the holy month or by accelerating the timing of purchases ahead of it. Finally, there are other non-spiritual benefits of Ramadan. Profiting from fasting can also come in the form of better health, and perhaps more important than any financial consideration, a slimmer waist. But of course, the authors of this paper will leave that phenomenon for the medical profession to tackle. 


\section{References}

Amihud, Y., 2002, Illiquidity and stock returns: Cross-section and time series effects, Journal of Financial Markets 5, No. 1, 31-56.

Amihud, Y. and H. Mendelson, 1986, Asset pricing and the bid-ask spread, Journal of Financial Economics 17, No. 2, 223-249.

Amihud, Y. and H. Mendelson, 1991, Liquidity, asset prices and financial policy, Financial Analysts Journal 47, No. 6, November-December, 56-66.

Ariel, Robert A. (1990). High stock returns before holidays: Existence and evidence on possible causes, Journal of Finance 45, No. 5, 1611-1626.

Banerjee, A. and E.W. Eckard, 2001, Why regulate insider trading? Evidence from the first great merger wave (1897-1903), American Economic Review 91, No. 5, 1329-1349.

Bartholdy, J., Boyle, G.W. and R.D. Stover, 2004. Deposit insurance and the stock market: evidence from Denmark, European Journal of Finance 10, No. 6, 567-578.

Beit-Hallahmi Benjamin and Michael Argyle, 1997. The Psychology of Religious Behaviour, Belief and Experience (Routledge, London).

Bernard, V.L., 1987, Cross-sectional dependence and problems in inference in market-based accounting research, Journal of Accounting Research 25, No. 1, 1-48.

Bhattacharya, U. and H. Daouk, 2002, The world price of insider trading. Journal of Finance 57, No. 1, pp. $75-108$.

Binder, J.J., 1985, On the use of the multivariate regression model in event studies, Journal of Accounting Research 23, No. 1, 370-383.

Binder, J.J., 1998, The event study methodology since 1969, Review of Quantitative Finance and Accounting 11, No. 2, 111-137.

Böck, D., Köhle, K, Weimann, G., Thomas, W., Mente, F., Schmidt, T., Jaeger, M., 1978, Prospective studies of the relationship between psychological and social symptoms with the long-term Success of hospital fasting therapy, Verhandlungen Der Deutschen Gesellschaft Fur Innere Medizin, 84, 1565-1567.

Bouhlel, E., Zaouali, M., Miled, A., Tabka, Z., Bigard, X. and R. Shephard, 2008, Ramadan fasting and the GH/IGF-1 axis of trained men during suboptimal exercise, Annals of Nutrition and Metabolism 52, No. 4, 261-266.

Bouman, S. and B. Jacobsen, 2002, The Halloween indicator, "Sell in May and go away": Another puzzle, American Economics Review 92, No. 5, 1618-1635. 
Brown, A. J., 2007, Low-carb diets, fasting and euphoria: Is there a link between ketosis and $\gamma$ hydroxybutyrate (GHB)?, Medical Hypotheses 68, 268-271.

Cadsby, C. B. and M. Ratner, 1992, Turn-of-month and pre-holiday effects on stock returns: Some international evidence, Journal of Banking and Finance 16, No. 3, 497-509.

Cambell, J.Y, Lo, A.W. and A.C. MacKinlay, 1997. The Econometrics of Financial Markets (Princeton University Press, Princeton, NJ).

Central Intelligence Agency, 2009. The World Handbook. (Available online at https://www.cia.gov/library/publications/download/ - last accessed 6 April 2009).

Chamberlain, G., 1978, Omitted variable bias in panel data: Estimating the returns to schooling, Annales de L'Insee 30-31, 49-82.

Cornett, M.M. and H. Tehranian, 1990, An examination of the impact of the Garn-St. Germain Depository Institutions Act of 1982 on commercial banks and savings and loans, Journal of Finance 45, No. 1, 95-111.

Crack, T.F., 1999, A classic case of data snooping for classroom discussion, The Journal of Financial Education 25, Fall, 92-97.

Cross, F., 1973, The Behavior of Stock Prices on Fridays and Mondays, Financial Analysts Journal 29, No. 6, November-December, 67-69.

Daniel, W.W., 1978. Applied Nonparametric Statistics (Houghton Mifflin Co., Boston, MA).

Daradkeh, T.K., 1992, Parasuicide during Ramadan in Jordan, Acta Psychiatrica Scandinavica 86, No. 3, 253-254.

Dowling, M. and B.M. Lucey, 2005, Weather, biorhythms, beliefs and stock returns - Some preliminary Irish evidence, International Review of Financial Analysis 14, No. 3, 337-355.

Edmans, A., Garcia, D. and O. Norli, 2007, Sports sentiment and stock returns, Journal of Finance 62, No. 4, 1967-1998.

Edwards, R.D., 2008, Health risk and portfolio choice, Journal of Business \& Economic Statistics 26, No. $4,472-485$.

Ellision, C.G., Burdette, A.M. and T.D. Hill, 2009, Blessed assurance: Religion, anxiety, and tranquility among US adults, Social Science Research 38, No. 3, 656-667.

Fama, E.F., 1998, Market efficiency, long-term returns, and behavioral finance, Journal of Financial Economics 49, No. 3, 283-306.

French, K.R., 1980, Stock returns and the weekend effect, Journal of Financial Economics 8, No. 1, 5569. 
Frieder, L. and A. Subrahmanyam, 2004, Non-secular regularities in returns and volume, Financial Analysts Journal 60, No. 4, July/August, 29-34.

Fuhrman, J., 1998. Fasting and Eating for Health. A Medical Doctor's Program for Conquering Disease (St. Martin's Press, New York, NY).

Gibbons, M.R. and P. Hess, 1981, Day of the week effects and asset returns, Journal of Business 54, No. 4, 579-596.

Gultekin, M.N and N.B. Gultekin, 1983, Stock market seasonality, Journal of Financial Economics 12, No. 4, 469-481.

Haugen, R.A. and N.L. Baker, 1996, Commonality in the determinants of expected stock returns, Journal of Financial Economics 41, No. 3, 401-439.

Hilary, G. and K.W. Hui, 2009, Does religion matter in corporate decision making in America?, Journal of Financial Economics 93, No. 3, 455-473.

Hirshleifer, D., 2001, Investor psychology and asset pricing, Journal of Finance 56, No. 4, 1533-1598.

Hirshleifer, D. and T. Shumway, 2003, Good day sunshine: Stock returns and the weather, Journal of Finance 58, No. 3, 1009-1032.

Hong, H. and M. Kacperczyk, 2009, The price of sin: The effects of social norms on markets, Journal of Financial Economics 93, No. 1, 15-36.

Izam, H.Y., 1978, An empirical analysis of the economic effects of mandatory government audit requirements, Ph.D. dissertation, University of Chicago.

Jaffe, J.F., 1974, Special Information and Insider Trading, Journal of Business, Vol. 47, No. 3, 410-428.

Kamstra, M.J., Kramer, L.A. and M.D. Levi, 2000, Losing sleep at the market: The daylight saving anomaly, American Economic Review 90, No. 4, 1005-1011.

Kamstra, M.J., Kramer, L.A. and M.D. Levi, 2003, Winter blues: A SAD stock market cycle, American Economic Review 93, No. 1, 324-343.

Kanji, G.K., 1993. 100 Statistical Tests (SAGE Publications, Newbury Park, CA).

Keim, D.B., 1983, Size-related anomalies and stock return seasonality, Journal of Financial Economics 12, No. 1, 13-32.

Keim, D.B. and R.F. Stambaugh, 1984, A further investigation of the weekend effect in stock prices, Journal of Finance 39, No. 3, 819-835.

Knerr, I. and P.L. Pearl, 2008, Ketogenic diet: Stoking energy stores and still posing questions, Experimental Neurology 11, 11-13. 
Kothari, S.P and J.B. Warner, 2007. Econometrics of event studies in B. Espen Eckbo, ed.: Handbook of Corporate Finance: Empirical Corporate Finance (Elsevier/North-Holland, Amsterdam).

Lakonishok, J. and S. Smidt, 1988, Are seasonal anomalies real? A ninety-year perspective, Revien of Financial Studies 1, No. 4, 403-425.

Loewenstein, G., 1996, Out of control: Visceral influences on behavior, Organizational Behavior and Human Decision Processes, 65, No. 3, 272-292.

Loewenstein, G., Weber, E.U., Hsee, C.K. and N. Welch, 2001, Risk as feelings, Psychological Bulletin 127, No. 2, 267-286.

Lucey, B. and M. Dowling, 2005, The role of feelings in investor decision-making, Journal of Economic Surveys 19, No. 2, 211-239

Mitchell, M.L. and E. Stafford, 2000, Managerial Decisions and Long-Term Stock Price Performance, Journal of Business 73, No. 3, 287-329.

Myers, D. G., 1993. The Pursuit of Happiness: Who is Happy, and Why? (Harper Paperbacks - Avon, New York, NY).

Perk, G., Ghanem, J., Aamar, S., Ben-Ishay, D. and M. Bursztyn, 2001, The effect of the fast of Ramadan on ambulatory blood pressure in treated hypertensives, Journal of Human Hypertension $15,723-725$.

Reinganum, M.R., 1983, The anomalous stock market behavior of small firms in January: Empirical tests for tax-loss selling effects, Journal of Financial Economics 12, No. 1, 89-104.

Rosen, H.S. and S. Wu, 2004, Portfolio choice and health status, Journal of Financial Economics 72, No. 3, 457-484.

Rozeff, M.S. and W.R. Kinney, Jr., 1976, Capital market seasonality: The case of stock returns, Journal of Financial Economics 3, No. 4, 379-402.

Saleh, S.A., Elsharouni, S.A., Cherian, B. and M. Mourou, 2005, Effects of Ramadan fasting on waist circumference, blood pressure, lipid profile, and blood sugar on a sample of healthy Kuwaiti men and women, Malaysian Journal of Nutrition, 11, No. 2, 143-150.

Seyyed F., Abraham, A. and M. Al-Hajji, 2005, Seasonality in stock returns and volatility: The Ramadan effect, Research in International Business and Finance 19, No. 3, 374-383

Seligman, M., 2003. Authentic Happiness (Nicholas Brealey, London).

Shiller, R., 2000. Irrational Exuberance (Princeton University Press, Princeton, NJ).

Schipper, K. and R. Thompson, 1983, The impact of merger-related regulations on the shareholders of acquiring firms, Journal of Accounting Research 21, No. 1, 184-221. 
Simon, H. A., 1967, Motivational and emotional controls of cognition. Psychological Review 74, No. 1, 29-39.

Mitchell, M.L. and E. Stafford, 2000, Managerial Decisions and Long-Term Stock Price Performance, Journal of Business 73, No. 3, 287-329.

Stulz, R.M. and R. Williamson, 2003, Culture, openness and finance, Journal of Financial Economics 70, No. 3, 313-349.

Subrahmanyam, A., 2007, Behavioural finance: A review and synthesis, European Financial Management 14, No. 1, 12-29.

Wagster, J.D., 1996, Impact of the 1988 Basle Accord on international banks, Journal of Finance 51, No. 4, 1321-1346.

Wagtendonk, K., 1968. Fasting in the Koran (E. J. Brill, Leiden, Netherlands).

Weber, M., 1905. The Protestant Ethic and the Spirit of Capitalism (Allen \& Unwin, London).

White, H., 1980, A heteroscedasticity-consistent covariance matrix estimator and a direct test for heteroscedasticity, Econometrica 48, No. 4, 817-838.

Wright, W. F. and G. H. Bower, 1992, Mood effects on subjective probability assessment, Organizational Behavior and Human Decision Processes 52, 276-291.

Yamamoto, H., 1980, An electroencephalographical study of fasting therapy with special reference to EEG power spectral changes, Japanese Journal of Psychosomatic Medicine 20, No. 4, 325-335.

Yamamoto, H., Suzuki, J., and Y. Yamauchi, 1979, Psychophysiological study on fasting therapy, Symposium on Strategies in Psychosomatic Practice and Research, Bodo, Norway, 1978, Psychotherapy and Psychosomatics 32, No. 1-4, 229-240.

Zellner, A., 1962, An efficient method of estimating seemingly unrelated regression equations and tests for aggregation bias. Journal of the American Statistical Association 57, 348-368. 
Figure 1

Annualized Raw Stock Returns during Ramadan and Non-Ramadan Periods

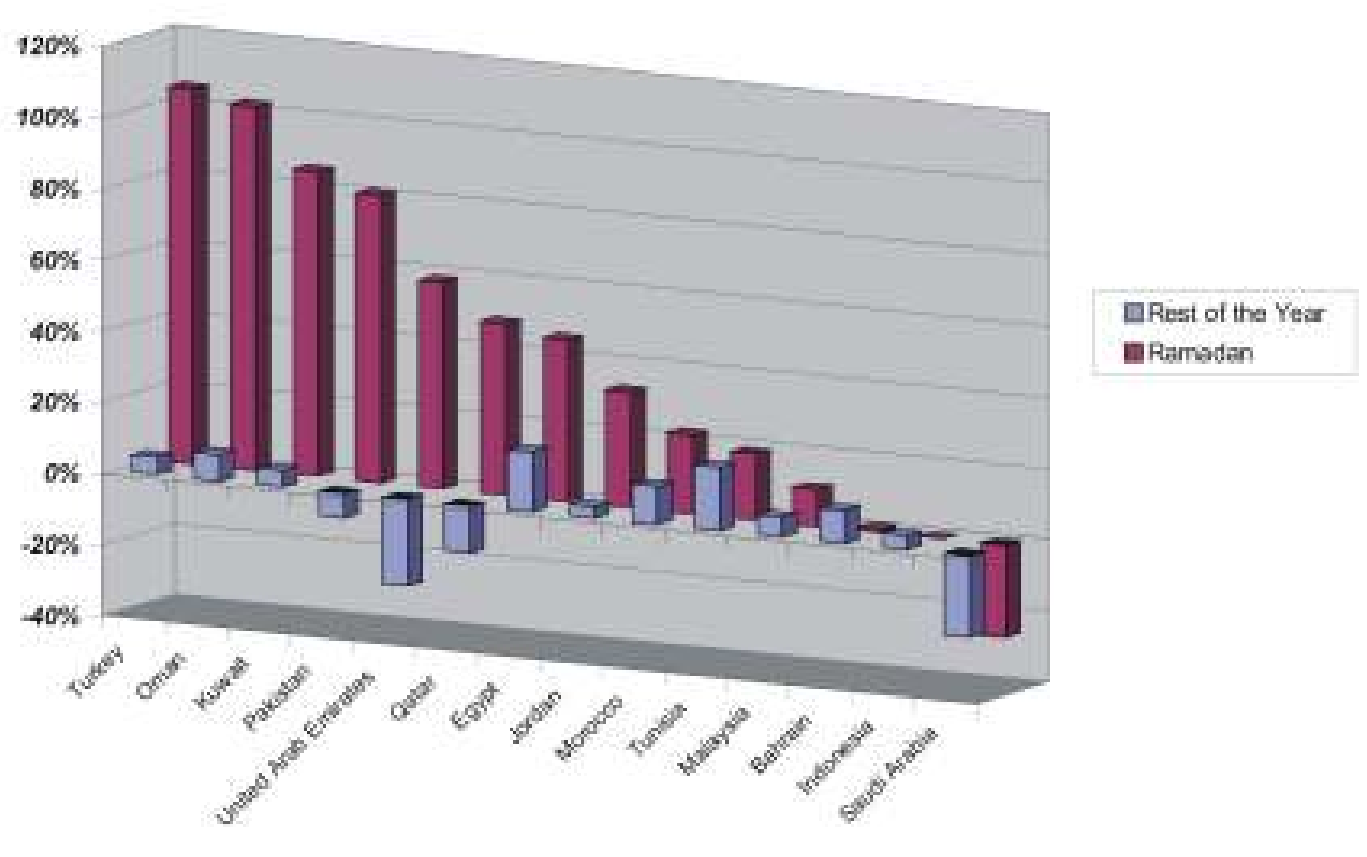

Note: This figure depicts annualized continuously compounded returns in fourteen predominantly Muslim countries during the holy month of Ramadan and throughout the rest of the year. All returns have been computed using the $\mathrm{MSCl}$ indices and are denominated in US dollars. 


\section{Figure 2}

\section{Cumulative Abnormal Returns during the Month of Ramadan}

Panel A: Constant-Mean-Return Model

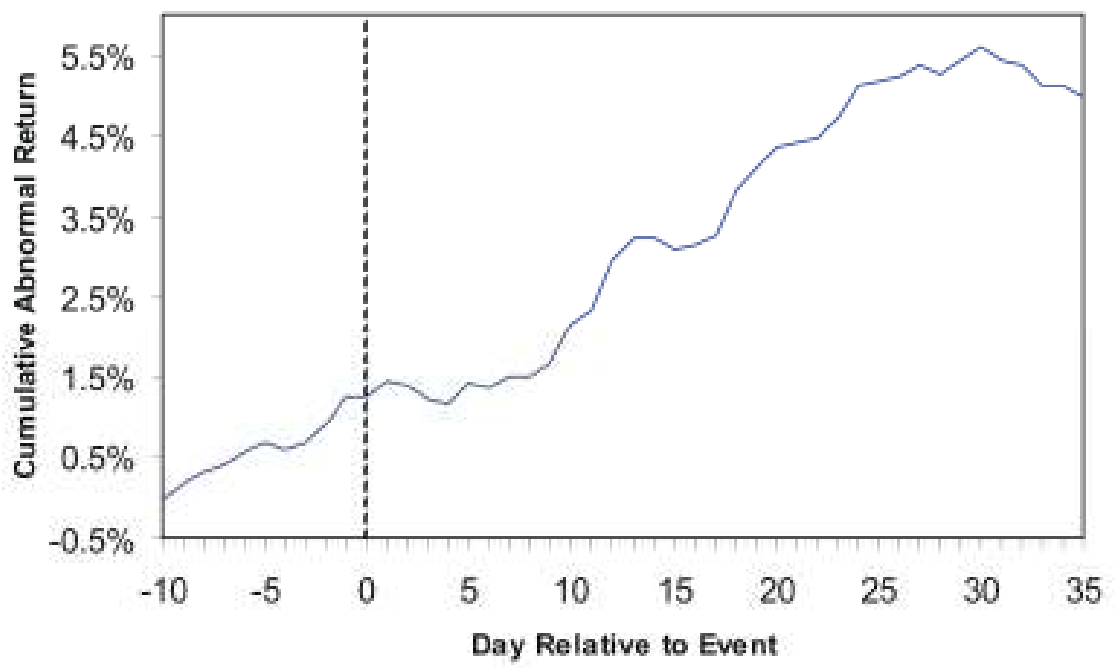

Panel B: Market Model

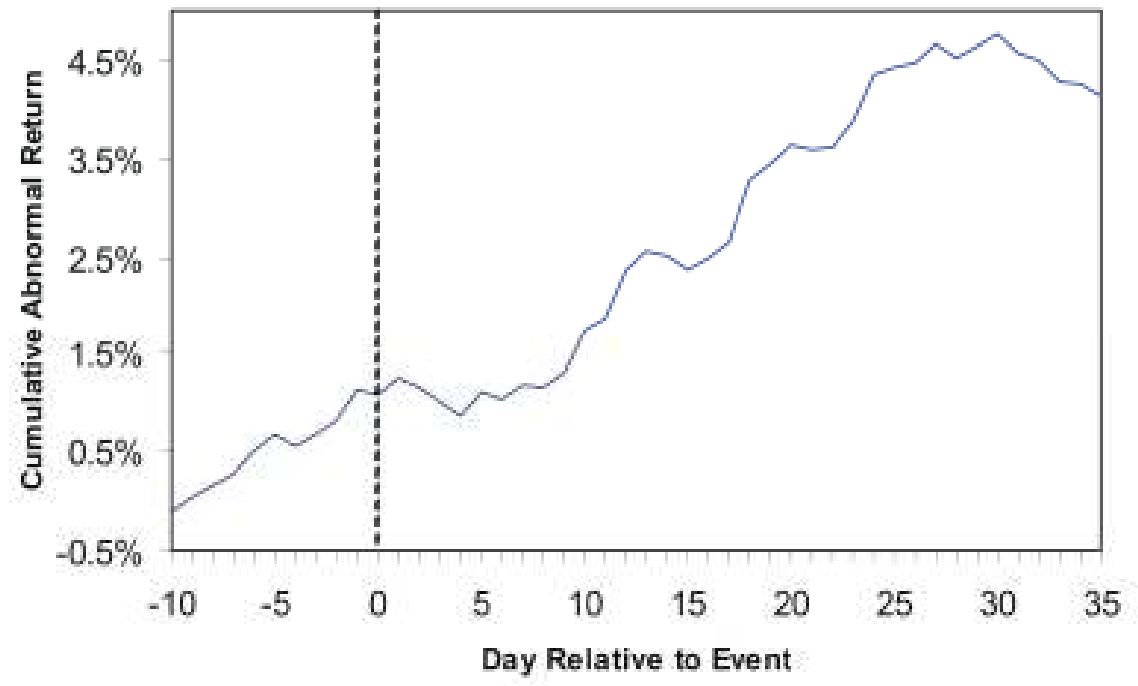

Note: The two panels above plot the Cumulative Abnormal Returns calculated for two different benchmark models. The total sample consists of 129 events in 14 predominantly Muslim nations. Day 0 on the graphs marks the beginning of Ramadan, which typically lasts around 21-22 trading days. 
Figure 3

\section{Rolling Average Volatility}

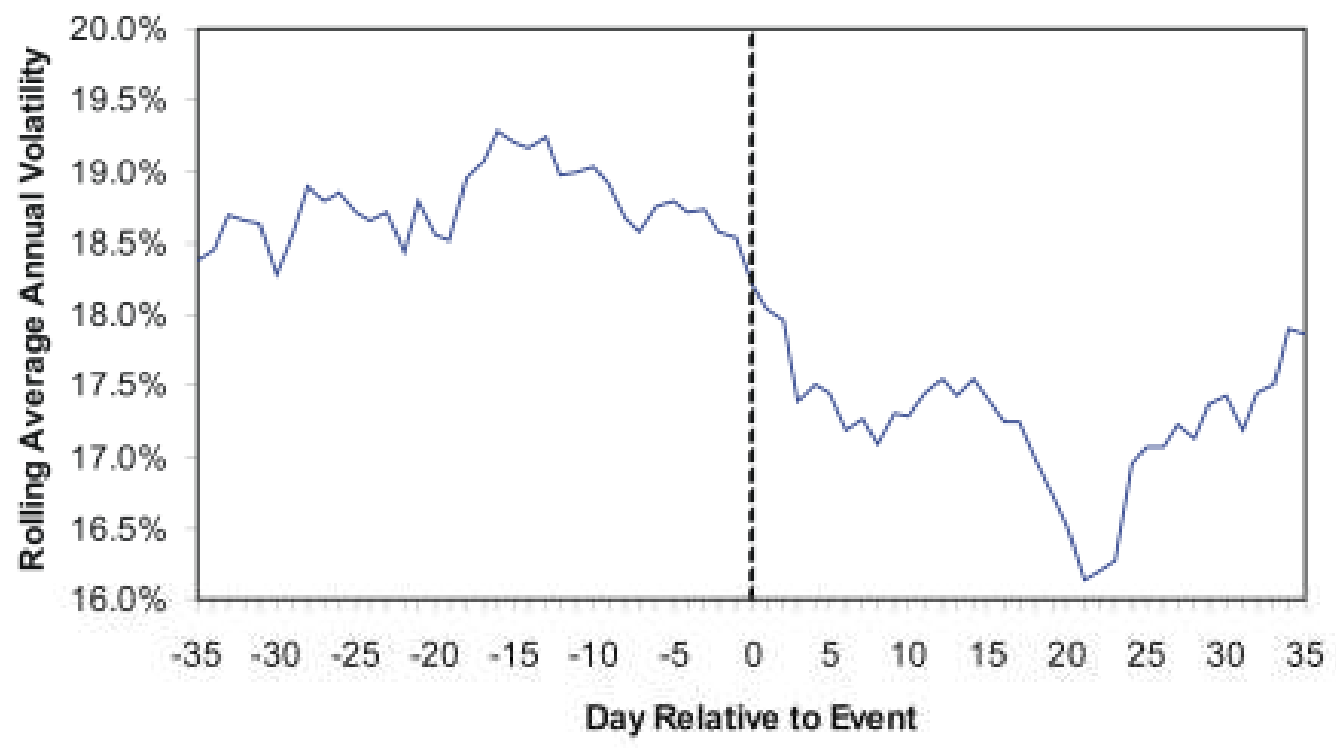

Note: This figure plots a geometric average of the annualized standard deviations of returns computed over 129 events. The volatility is measured over the last 20 trading days relative to a particular day in the event window. Day 0 denotes the start of Ramadan and days 20-21 on the graph above mark its end. 
Figure 4

\section{Average Daily Turnover}

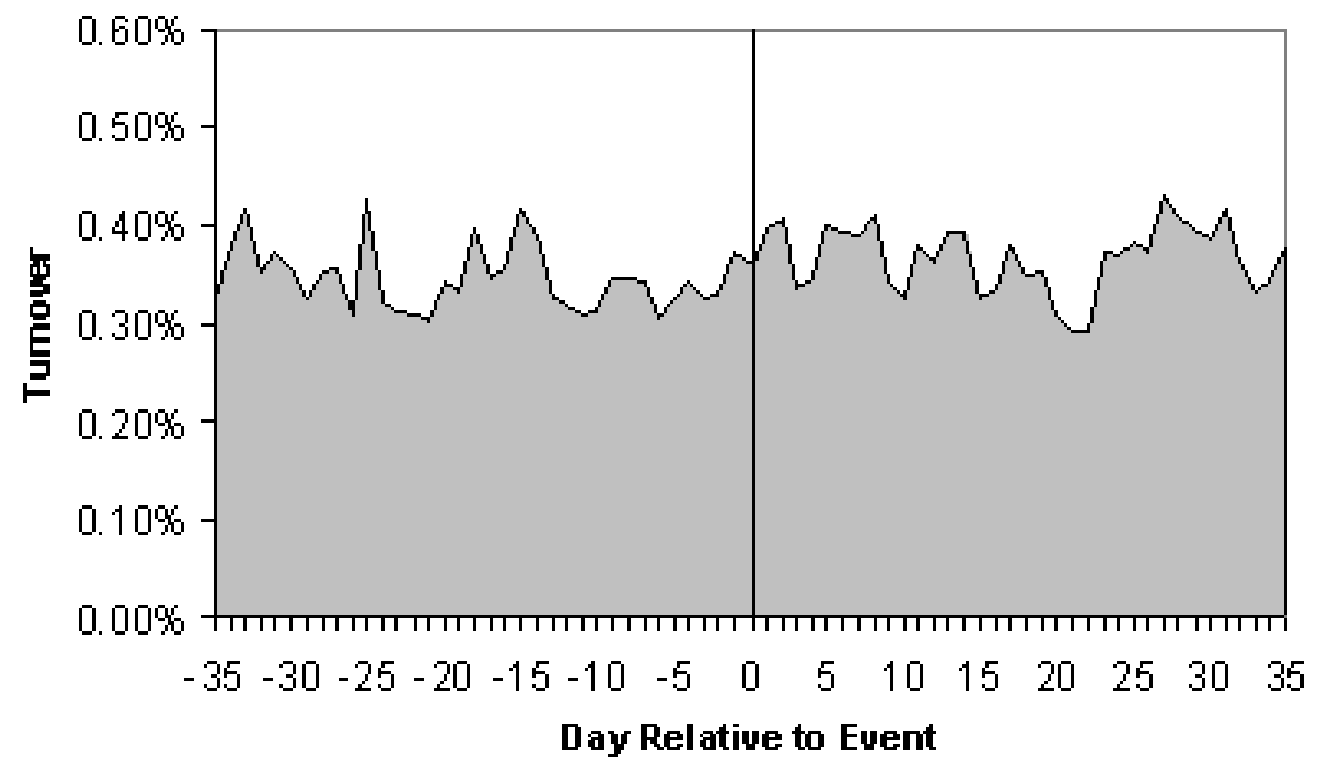

Note: This figure plots the total US dollar equivalent of daily trading volume in 364 companies listed in countries where Muslims account for the majority of population divided by their total US dollar market capitalization. The 71-day event window is centered on the Ramadan starting date. 


\section{Figure 5}

\section{Annualized Raw Returns on the S\&P Indices during Ramadan and Non-Ramadan Periods}

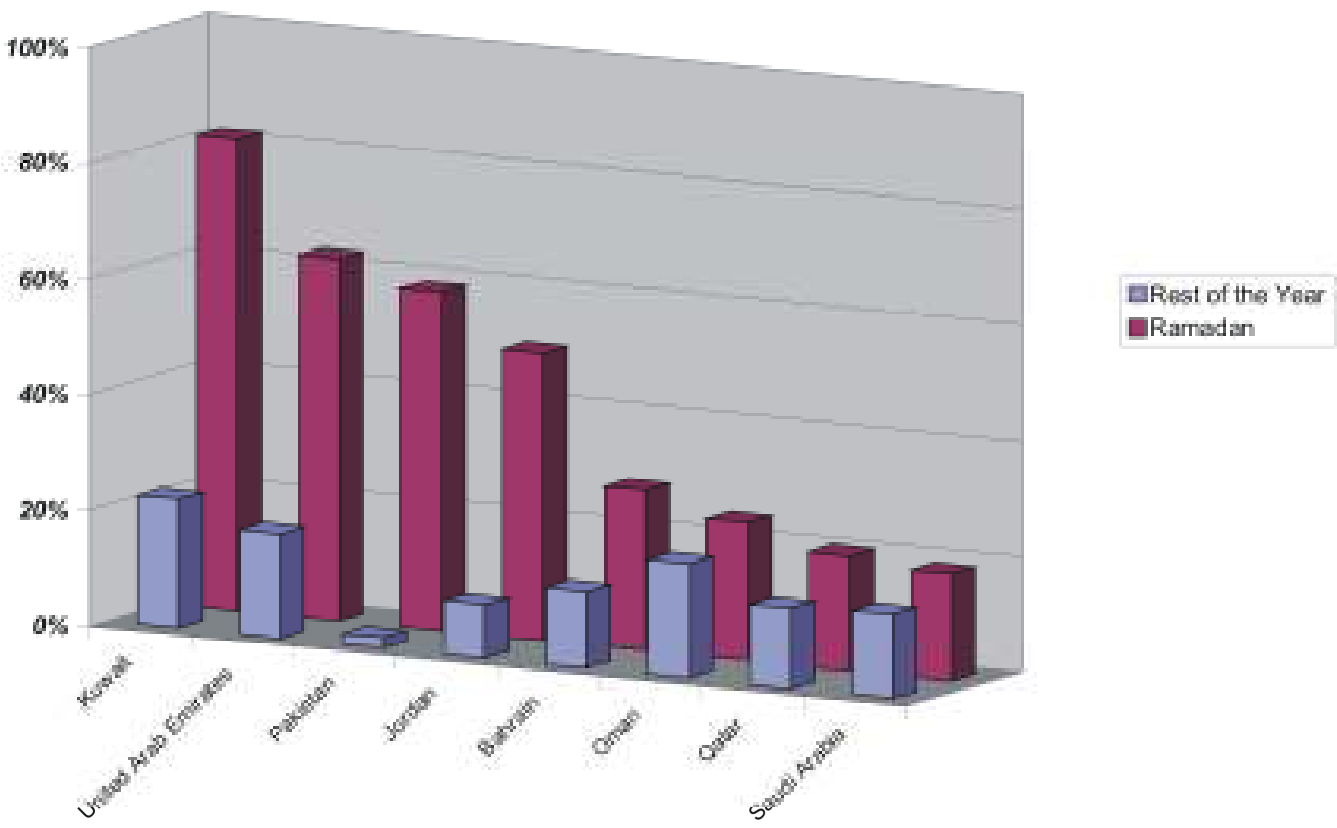

Note: This figure presents the annualized continuously compounded returns on the S\&P indices expressed in U.S. dollars. For the purposes of comparison, the returns have been calculated during the holy month of Ramadan and during all other months of the Islamic lunar year. The calculations are based on a sample of 59 events in 8 predominantly Muslim countries. 
Figure 6

Annualized Raw Returns during Ramadan and Non-Ramadan Periods in Different Sub-Samples

Panel A. Sample Excluding Events Starting in January

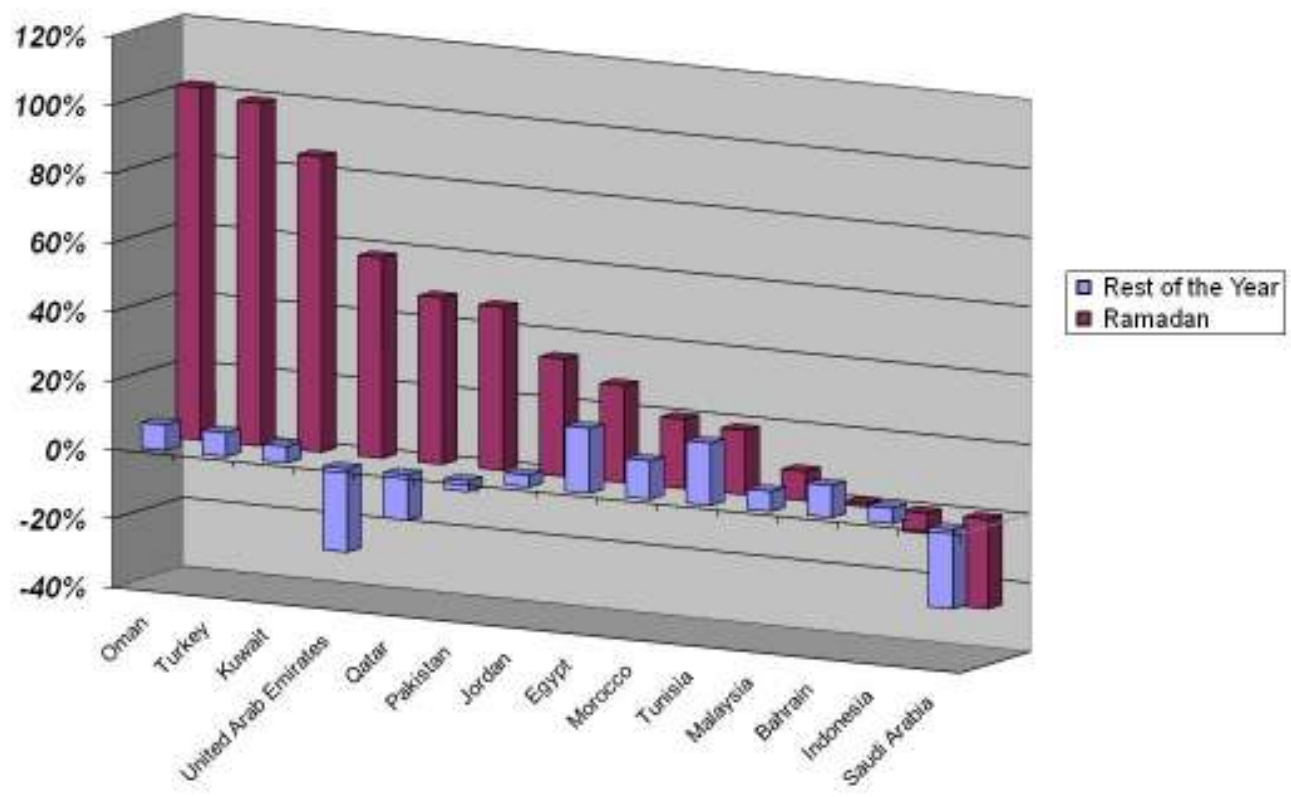

Panel B. Sample Excluding Events Starting between November and April

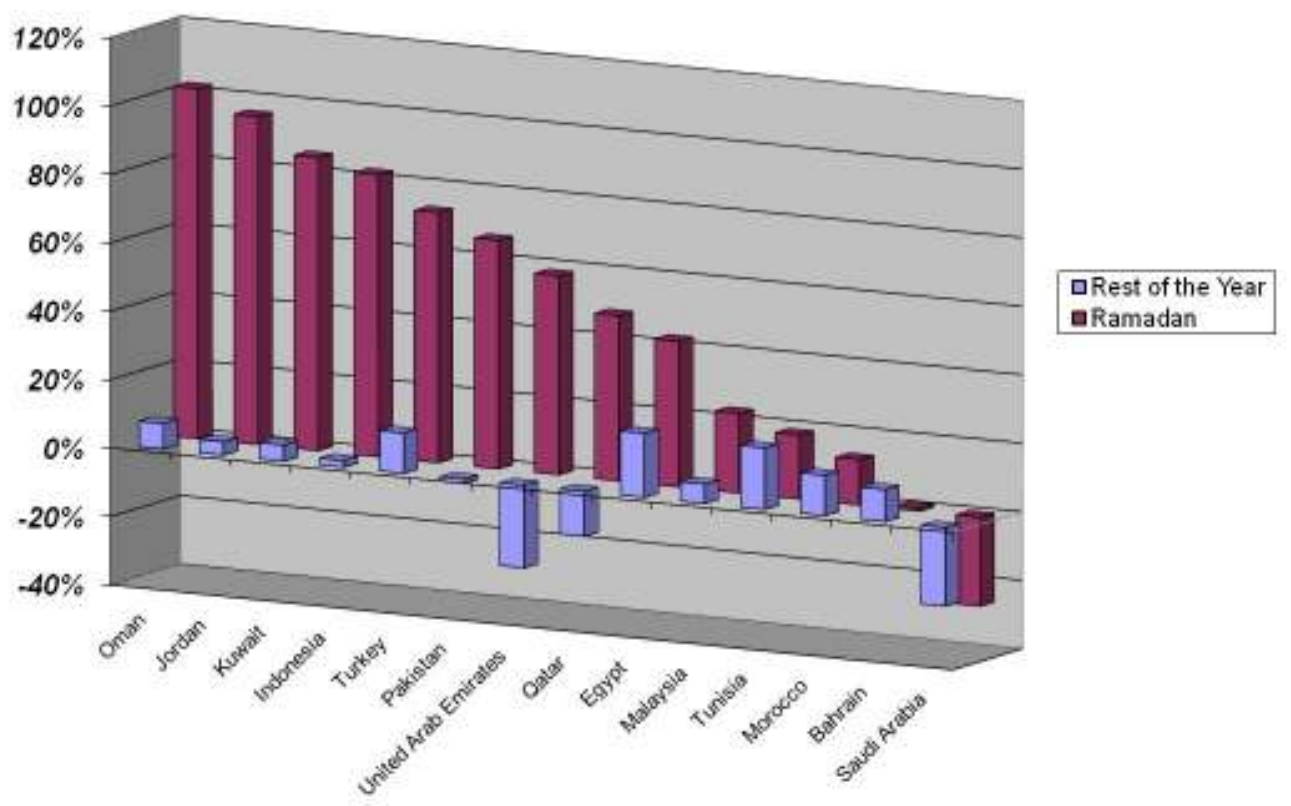

Note: This figure plots the annualized continuously compounded US dollar denominated returns on the $\mathrm{MSCl}$ indices during the holy month and the rest of the lunar year. Panel A considers all of the 115 events, which did not start in the month of January. Panel $\mathrm{B}$, on the other hand, 
reports results for 50 events, which did not commence in the period between November and April. 
Figure 7

Stability of the Ramadan Effect over Time

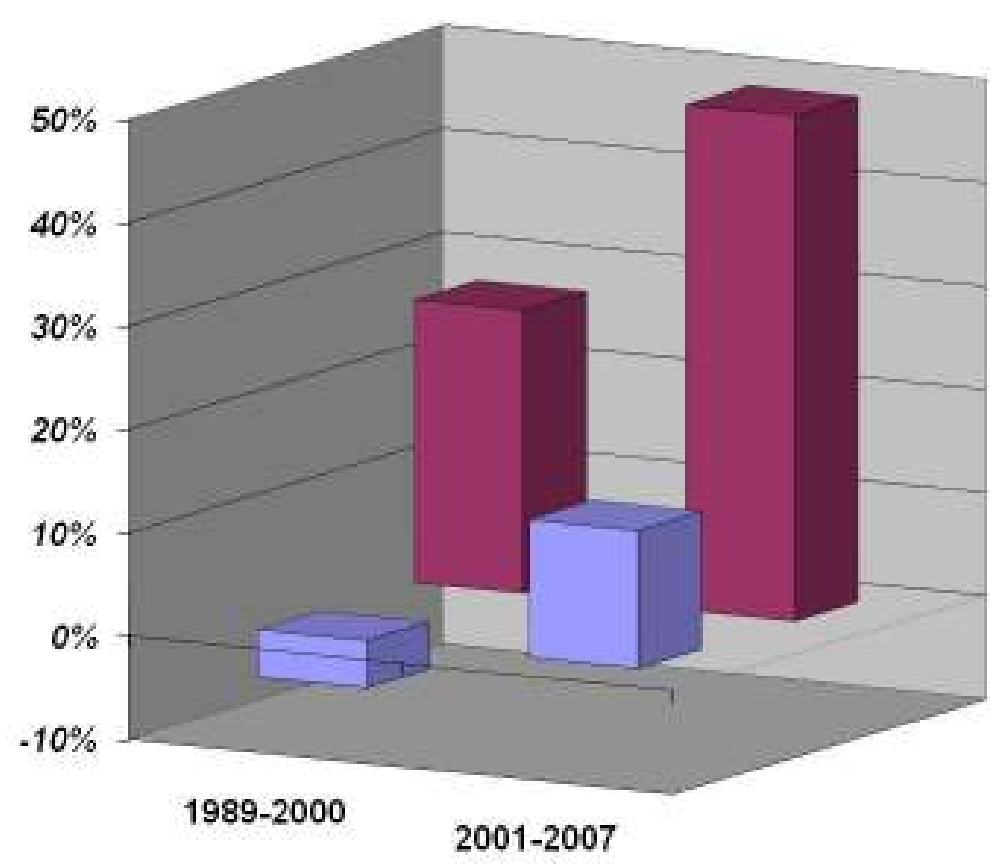

Note: This figure depicts returns during Ramadan and the rest of the year in two sub-periods. The first time interval from 1989 to 2000 comprises 65 events, while another 64 observations fall within the 2001-2007 period. The returns are annualized, continuously compounded and denominated in US dollars. 


\section{Table 1}

\section{Sample Composition}

This table lists the markets included in our analysis with the corresponding number of events. In order to be included in the sample, a country needed to have an $\mathrm{MSCl}$ stock market index in the DataStream database and a proportion of Muslims in total population exceeding 50\%. The data on population and religious fractionalization has been obtained from the Central Intelligence Agency (CIA) World Factbook (2009). In cases where the CIA did not record the exact proportion of Muslims in the society, the data was sourced from the Association of Religion Data Archives. The fourth column reports information on the direct foreign ownership by investors residing/headquartered outside the 14 countries listed in the table below. These statistics are capitalization-weighted, computed across all MSCI Index constituents and based on the ownership data available in the OSIRIS database. Since the dates of the holy month of Ramadan are determined by a lunar cycle observed at a particular geographical location, we have collected the coordinates of capital cities from the National Geospatial-Intelligence Agency. These coordinates are used subsequently to calculate the moon's phases from which the starting and ending dates of events are derived. MSCI Index Start Date is the date at which daily observations on a particular index become available.

\begin{tabular}{|c|c|c|c|c|c|c|c|c|}
\hline Country & Population & $\begin{array}{l}\text { Percent } \\
\text { Muslim }\end{array}$ & $\begin{array}{l}\text { Non-Muslim } \\
\text { Foreign } \\
\text { Ownership }\end{array}$ & Capital City & Latitude & Longitude & $\begin{array}{l}\text { MSCl Index } \\
\text { Start Date }\end{array}$ & $\begin{array}{l}\text { Number of } \\
\text { Observations }\end{array}$ \\
\hline Bahrain & 727,785 & $81.2 \%$ & $9.0 \%$ & Manama & $26014^{\prime} 10^{\prime \prime} \mathrm{N}$ & $050 \circ 34^{\prime} 59^{\prime \prime} \mathrm{E}$ & 31-May-05 & 2 \\
\hline Egypt & $83,082,869$ & $90.0 \%$ & $28.2 \%$ & Cairo & $30 \circ 03^{\prime} 00^{\prime \prime} \mathrm{N}$ & $031^{\circ} 15^{\prime} 00^{\prime \prime} \mathrm{E}$ & 30-Dec-94 & 13 \\
\hline Indonesia & $240,271,522$ & $86.1 \%$ & $21.2 \%$ & Jakarta & $06010^{\prime} 28^{\prime \prime} \mathrm{S}$ & $106949^{\prime} 46^{\prime \prime} \mathrm{E}$ & 31-Dec-87 & 20 \\
\hline Jordan & $6,342,948$ & $92.0 \%$ & $10.0 \%$ & Amman & $31^{\circ} 57^{\prime} 00^{\prime \prime} \mathrm{N}$ & $035 \circ 56^{\prime} 00^{\prime \prime} \mathrm{E}$ & 31-Dec-87 & 20 \\
\hline Kuwait & $2,691,158$ & $85.0 \%$ & $3.5 \%$ & Kuwait & $29022^{\prime} 11^{\prime \prime} \mathrm{N}$ & $047^{\circ} 58^{\prime} 42^{\prime \prime} \mathrm{E}$ & 31-May-05 & 2 \\
\hline Malaysia & $25,715,819$ & $60.4 \%$ & $14.9 \%$ & Kuala Lumpur & $03 \circ 10^{\prime} 00^{\prime \prime} \mathrm{N}$ & $101942^{\prime} 00^{\prime \prime} \mathrm{E}$ & 31-Dec-87 & 20 \\
\hline Morocco & $34,859,364$ & $98.7 \%$ & $28.5 \%$ & Rabat & $34^{\circ} 01^{\prime} 12^{\prime \prime} \mathrm{N}$ & $006049^{\prime} 48^{\prime \prime} \mathrm{W}$ & 30-Dec-94 & 13 \\
\hline Oman & $3,418,085$ & $89.2 \%$ & $3.6 \%$ & Muscat & $23 \cong 36^{\prime} 48^{\prime \prime} \mathrm{N}$ & $058^{\circ} 35^{\prime} 36^{\prime \prime} \mathrm{E}$ & 31-May-05 & 2 \\
\hline Pakistan & $176,242,949$ & $95.0 \%$ & $3.7 \%$ & Islamabad & $33 \circ 42^{\prime} 00^{\prime \prime} \mathrm{N}$ & $073 \circ 10^{\prime} 00^{\prime \prime} \mathrm{E}$ & 31-Dec-92 & 15 \\
\hline Qatar & 833,285 & $77.5 \%$ & $12.2 \%$ & Doha & $25017^{\prime} 12^{\prime \prime} \mathrm{N}$ & $051^{\circ} 32^{\prime} 00^{\prime \prime} \mathrm{E}$ & 31-May-05 & 2 \\
\hline
\end{tabular}




\begin{tabular}{|c|c|c|c|c|c|c|c|c|}
\hline Saudi Arabia & $28,686,633$ & $100 \%$ & $1.3 \%$ & Riyadh & $24038^{\prime} 27^{\prime \prime} \mathrm{N}$ & $046046^{\prime} 22^{\prime \prime} \mathrm{E}$ & 31-May-05 & 2 \\
\hline Tunisia & $10,486,339$ & $98 \%$ & $17.1 \%$ & Tunis & $36048^{\prime} 10^{\prime \prime} \mathrm{N}$ & $01010^{\prime} 47^{\prime \prime} \mathrm{E}$ & 31-May-04 & 3 \\
\hline Turkey & $76,805,524$ & $99.8 \%$ & $16.2 \%$ & Ankara & $39 \circ 55^{\prime} 38^{\prime \prime} \mathrm{N}$ & $032^{\circ} 51^{\prime} 52^{\prime \prime} \mathrm{E}$ & 31-May-94 & 13 \\
\hline United Arab Emirates & $4,798,491$ & $96.0 \%$ & $1.9 \%$ & Abu Dhabi & $24 \div 28^{\prime} 00^{\prime \prime} \mathrm{N}$ & 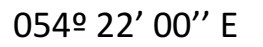 & 31-May-05 & 2 \\
\hline Total & $694,962,771$ & $90.9 \%$ & $9.1 \%$ & & & & & 129 \\
\hline
\end{tabular}




\section{Cumulative Abnormal Returns}

This table reports cumulative abnormal returns around the holy month of Ramadan along with the results of statistical significance tests. The cumulative abnormal returns are expressed in US dollars and have been computed based on a sample of 129 events. Panel A defines the abnormal returns as the returns in excess of a mean return averaged over a 200-day pre-event window, whereas Panel B expresses the abnormal returns as deviations from the predictions of the market model. The third and fourth columns present $t$-statistics with the corresponding $p$-values for the hypothesis that the Cumulative Abnormal Returns equal zero. The last three columns in the table report the results of the non-parametric sign test. Under the null hypothesis that the proportion of positive cumulative abnormal returns in the whole sample equals $50 \%$ the $z$-statistic is normally distributed with mean zero and standard deviation of one.

\begin{tabular}{|c|c|c|c|c|c|c|}
\hline \multicolumn{7}{|c|}{ Panel A. Constant-Mean-Return Model } \\
\hline $\begin{array}{c}\text { Event } \\
\text { Window }\end{array}$ & CAR & $t$-stat & $p$-value & $\begin{array}{l}\text { Proportion of } \\
\text { Positive CARs }\end{array}$ & z-stat & $p$-value \\
\hline$(0,5)$ & $0.1440 \%$ & 0.3574 & 0.7214 & 0.5271 & 0.6172 & 0.5371 \\
\hline$(0,10)$ & $0.8995 \%$ & 1.4040 & 0.1627 & 0.5891 & 2.0580 & 0.0396 \\
\hline$(0,20)$ & $3.0788 \%$ & 3.0310 & 0.0030 & 0.6357 & 3.2017 & 0.0014 \\
\hline$(0,21)$ & $3.1105 \%$ & 3.0462 & 0.0028 & 0.6047 & 2.4311 & 0.0151 \\
\hline$(0,30)$ & $4.2727 \%$ & 3.9342 & 0.0001 & 0.6512 & 3.6023 & 0.0003 \\
\hline$(-10,20)$ & $4.3763 \%$ & 4.0590 & 0.0001 & 0.6124 & 2.6204 & 0.0088 \\
\hline$(-10,21)$ & $4.4103 \%$ & 4.0727 & 0.0001 & 0.6047 & 2.4311 & 0.0151 \\
\hline$(-10,35)$ & $4.9882 \%$ & 3.8833 & 0.0002 & 0.5814 & 1.8739 & 0.0609 \\
\hline \multicolumn{7}{|c|}{ Panel B. Market Model } \\
\hline $\begin{array}{c}\text { Event } \\
\text { Window }\end{array}$ & CAR & $t$-stat & $p$-value & $\begin{array}{l}\text { Proportion of } \\
\text { Positive CARs }\end{array}$ & $z$-stat & $p$-value \\
\hline$(0,5)$ & $-0.0345 \%$ & 0.0867 & 0.9310 & 0.5116 & 0.2642 & 0.7916 \\
\hline$(0,10)$ & $0.6054 \%$ & 0.3757 & 0.7078 & 0.5891 & 2.0580 & 0.0396 \\
\hline
\end{tabular}




\begin{tabular}{ccccccc}
$(0,20)$ & $2.4798 \%$ & 2.5376 & 0.0124 & 0.6357 & 3.2017 & 0.0014 \\
$(0,21)$ & $2.4381 \%$ & 2.4651 & 0.0150 & 0.6434 & 3.4005 & 0.0007 \\
$(0,30)$ & $3.5754 \%$ & 3.2649 & 0.0014 & 0.6667 & 4.0156 & 0.0001 \\
$(-10,20)$ & $3.6306 \%$ & 3.4483 & 0.0008 & 0.6357 & 3.2017 & 0.0014 \\
$(-10,21)$ & $3.5962 \%$ & 3.3826 & 0.0010 & 0.6357 & 3.2017 & 0.0014 \\
$(-10,35)$ & $4.1363 \%$ & 3.2200 & 0.0016 & 0.6047 & 2.4311 & 0.0151 \\
\hline
\end{tabular}


Table 3

\section{Return Volatility during Ramadan and the Rest of the Year}

This table juxtaposes the arithmetic averages of annualized unconditional standard deviations of returns during the holy month of Ramadan and all the remaining months of the Islamic calendar. The statistical significance of the average difference between these two estimates is tested using a Wilcoxon signed-ranks test. In large samples, the Wilcoxon test statistic has approximately a standard normal distribution under the null.

\begin{tabular}{lccc}
\hline & Ramadan & $\begin{array}{c}\text { Rest of the } \\
\text { Year }\end{array}$ & Difference \\
\hline Bahrain & $8.5432 \%$ & $16.7052 \%$ & $-8.1620 \%$ \\
Egypt & $21.2382 \%$ & $22.5039 \%$ & $-1.2657 \%$ \\
Indonesia & $31.0700 \%$ & $32.9271 \%$ & $-1.8570 \%$ \\
Jordan & $10.4508 \%$ & $16.0438 \%$ & $-5.5930 \%$ \\
Kuwait & $11.1855 \%$ & $21.5666 \%$ & $-10.3811 \%$ \\
Malaysia & $18.8060 \%$ & $22.8885 \%$ & $-4.0825 \%$ \\
Morocco & $12.1587 \%$ & $13.0228 \%$ & $-0.8641 \%$ \\
Oman & $10.7488 \%$ & $14.5779 \%$ & $-3.8290 \%$ \\
Pakistan & $24.2362 \%$ & $29.7812 \%$ & $-5.5450 \%$ \\
Qatar & $20.1577 \%$ & $23.6476 \%$ & $-3.4899 \%$ \\
Saudi Arabia & $18.3109 \%$ & $42.9538 \%$ & $-24.6428 \%$ \\
Tunisia & $9.1412 \%$ & $14.2941 \%$ & $-5.1529 \%$ \\
Turkey & $59.0653 \%$ & $47.7005 \%$ & $11.3649 \%$ \\
United Arab Emirates & $13.2271 \%$ & $28.6732 \%$ & $-15.4461 \%$ \\
\hline Total & $22.9757 \%$ & $25.6201 \%$ & $-2.6444 \%$ \\
\hline Wilcoxon test statistic & & & -4.9657 \\
\hline
\end{tabular}




\section{Table 4}

\section{Cumulative Abnormal Returns Calculated According to the Saudi Lunar Cycle}

This table reports cumulative abnormal returns around the holy month of Ramadan along with the results of statistical significance tests. The cumulative abnormal returns are expressed in US dollars and have been computed based on a sample of 129 events. It is assumed here that a sighting of new moon in Makkah determines both the starting and ending dates of the Ramadan fast. Panel A defines the abnormal returns as the returns in excess of a mean return averaged over a 200-day pre-event window, whereas Panel B expresses the abnormal returns as deviations from the predictions of the market model. The third and fourth columns present $t$-statistics with the corresponding $p$-values for the hypothesis that the Cumulative Abnormal Returns equal zero. The last three columns in the table report the results of the nonparametric sign test. Under the null hypothesis that the proportion of positive cumulative abnormal returns in the whole sample equals $50 \%$ the $z$-statistic is normally distributed with mean zero and standard deviation of one.

\begin{tabular}{|c|c|c|c|c|c|c|}
\hline \multicolumn{7}{|c|}{ Panel A. Constant-Mean-Return Model } \\
\hline $\begin{array}{c}\text { Event } \\
\text { Window }\end{array}$ & CAR & $t$-stat & $\mathrm{p}$-value & $\begin{array}{l}\text { Proportion of } \\
\text { Positive CARs }\end{array}$ & z-stat & $\mathrm{p}$-value \\
\hline$(0,20)$ & $3.0471 \%$ & 2.9901 & 0.0033 & 0.6279 & 3.0055 & 0.0027 \\
\hline$(0,21)$ & $3.1174 \%$ & 3.0543 & 0.0027 & 0.6357 & 3.2017 & 0.0014 \\
\hline \multicolumn{7}{|c|}{ Panel B. Market Model } \\
\hline $\begin{array}{c}\text { Event } \\
\text { Window }\end{array}$ & CAR & $t$-stat & p-value & $\begin{array}{l}\text { Proportion of } \\
\text { Positive CARs }\end{array}$ & z-stat & $\mathrm{p}$-value \\
\hline$(0,20)$ & $2.4587 \%$ & 2.5011 & 0.0136 & 0.6202 & 2.8118 & 0.0049 \\
\hline$(0,21)$ & $2.4520 \%$ & 2.4776 & 0.0145 & 0.6047 & 2.4311 & 0.0151 \\
\hline
\end{tabular}


Correlation between the Length of the Day (From Sunrise to Sunset) and the Cumulative Abnormal Returns

This table reports the correlation coefficients between the cumulative abnormal returns and the length of the within-day fast. For each event, the within-day fasting period has been calculated as the time (in minutes) between sunrise and sunset on the Ramadan's first day of trading. Panel A reports the correlations between the daily fast duration and the cumulative abnormal returns computed relative to a mean return from the 200-day pre-event window. Panel B, on the other hand, presents the correlation coefficients with the cumulative abnormal returns defined in terms of deviations from the market model predictions. Under the null hypothesis of no linear association, the test statistic follows a $t$-distribution with 127 degrees of freedom.

\begin{tabular}{|c|c|c|c|c|}
\hline \multicolumn{5}{|c|}{ Panel A. Constant-Mean-Return Model } \\
\hline & $\operatorname{CAR}(0,20)$ & $\operatorname{CAR}(0,21)$ & $\operatorname{CAR}(0,30)$ & $\operatorname{CAR}(-10,35)$ \\
\hline Correlation Coefficient & -0.0788 & -0.0715 & -0.0788 & -0.0448 \\
\hline$t$-statistic & -0.8906 & -0.8073 & -0.8906 & -0.5052 \\
\hline$p$-value & 0.3748 & 0.4210 & 0.3748 & 0.6143 \\
\hline \multicolumn{5}{|l|}{ Panel B. Market Model } \\
\hline & $\operatorname{CAR}(0,20)$ & $\operatorname{CAR}(0,21)$ & $\operatorname{CAR}(0,30)$ & $\operatorname{CAR}(-10,35)$ \\
\hline Correlation Coefficient & -0.0984 & -0.0903 & -0.0638 & -0.0404 \\
\hline$t$-statistic & -1.1141 & -1.0223 & -0.7209 & -0.4554 \\
\hline$p$-value & 0.2673 & 0.3086 & 0.4723 & 0.6496 \\
\hline
\end{tabular}


Table 6

\section{Controlling for Other Calendar Anomalies: Pooled OLS and Panel Estimations}

The regressions reported in this table examine the statistical significance of seasonal regularities in the dollar-denominated returns in fourteen predominantly Muslim countries. Daily continuously compounded returns on the $\mathrm{MSCl}$ indices expressed in percentage terms have been used as a dependent variable in all of the specifications. Panel $A$ assumes an equal intercept across all countries, whereas the regressions reported in Panel B include country-specific fixed effects. Ramadan is a dummy variable for the Muslim holy month observed according to the local lunar cycle. Halloween takes the value of 1 during the November-April period and 0 otherwise. January and Monday are indicator variables for the first month of the year and first day of the week, respectively. Return_World is the continuously compounded return on the value-weighted MSCI World Index comprising 23 industrialized countries. The regressions in presented in this table are based on an unbalanced panel. The length of the series for each of the countries is determined by data availability described in Table 1 . Coefficient standard errors are reported in parentheses. ${ }^{* * *},{ }^{* *}$, * denote statistical significance at $1 \%, 5 \%$ and $10 \%$, respectively.

\begin{tabular}{lcccc}
\hline Panel A. Pooled OLS Estimation & \multicolumn{5}{l}{} \\
\hline & $(1)$ & $(2)$ & $(3)$ & $(4)$ \\
\hline Intercept & 0.0038 & -0.0254 & -0.0252 & 0.0018 \\
& $(0.0116)$ & $(0.0156)$ & $(0.0156)$ & $(0.0165)$ \\
Ramadan & $0.1042^{* * *}$ & $0.0914^{* *}$ & $0.0868^{* *}$ & $0.0882^{* *}$ \\
& $(0.0387)$ & $(0.0390)$ & $(0.0390)$ & $(0.0390)$ \\
Halloween & & $0.0622^{* * *}$ & $0.0407^{*}$ & $0.0405^{*}$ \\
& & $(0.0222)$ & $(0.0234)$ & $(0.0234)$ \\
January & & & $0.1215^{* * *}$ & $0.1223^{* * *}$ \\
& & & $(0.0412)$ & $(0.0412)$ \\
Monday & & & & $-0.1355^{* * *}$ \\
& & & & $(0.0275)$ \\
Return_World & $0.1900^{* * *}$ & $0.1892^{* * *}$ & $0.1896^{* * *}$ & $0.1891^{* * *}$ \\
& $(0.0141)$ & $(0.0141)$ & $(0.0141)$ & $(0.0141)$ \\
Return_World_Lag & $0.2386^{* * *}$ & $0.2376^{* * *}$ & $0.2385^{* * *}$ & $0.2385^{* * *}$ \\
& $(0.0141)$ & $(0.0141)$ & $(0.0141)$ & $(0.0141)$ \\
\hline Adjusted R-square & 0.0179 & 0.0181 & 0.0184 & 0.0191 \\
\hline
\end{tabular}

Panel B. Fixed Effect Panel Estimation

\begin{tabular}{lcccc}
\hline & $(1)$ & $(2)$ & $(3)$ & $(4)$ \\
\hline Ramadan & $0.1043^{* * *}$ & $0.0916^{* *}$ & $0.0870^{* *}$ & $0.0885^{* *}$
\end{tabular}




\begin{tabular}{|c|c|c|c|c|}
\hline & $(0.0387)$ & $(0.0390)$ & $(0.0390)$ & (0.0390) \\
\hline Halloween & & $\begin{array}{l}0.0614^{* * *} \\
(0.0222)\end{array}$ & $\begin{array}{c}0.0396^{*} \\
(0.0234)\end{array}$ & $\begin{array}{c}0.0394^{*} \\
(0.0234)\end{array}$ \\
\hline January & & & $\begin{array}{l}0.1229^{* * *} \\
(0.0412)\end{array}$ & $\begin{array}{l}0.1238^{* * *} \\
(0.0412)\end{array}$ \\
\hline Monday & & & & $\begin{array}{l}-0.1354^{* * *} \\
(0.0275)\end{array}$ \\
\hline Return_World & $\begin{array}{c}0.1903^{* * *} \\
(0.0141)\end{array}$ & $\begin{array}{c}0.1895^{* * *} \\
(0.0141)\end{array}$ & $\begin{array}{c}0.1899^{* * *} \\
(0.0141)\end{array}$ & $\begin{array}{c}0.1895^{* * *} \\
(0.0141)\end{array}$ \\
\hline Return_World_Lag & $\begin{array}{c}0.2389^{* * *} \\
(0.0141)\end{array}$ & $\begin{array}{c}0.2379^{* * *} \\
(0.0141)\end{array}$ & $\begin{array}{l}0.2388^{* * *} \\
(0.0141)\end{array}$ & $\begin{array}{c}0.2388^{* * *} \\
(0.0141)\end{array}$ \\
\hline \multicolumn{5}{|l|}{ Fixed Effects } \\
\hline Bahrain & $\begin{array}{l}-0.0134 \\
(0.0903)\end{array}$ & $\begin{array}{l}-0.0404 \\
(0.0908)\end{array}$ & $\begin{array}{l}-0.0417 \\
(0.0908)\end{array}$ & $\begin{array}{l}-0.0149 \\
(0.0909)\end{array}$ \\
\hline Egypt & $\begin{array}{c}0.0528 \\
(0.0352)\end{array}$ & $\begin{array}{c}0.0238 \\
(0.0367)\end{array}$ & $\begin{array}{c}0.0242 \\
(0.0367)\end{array}$ & $\begin{array}{c}0.0512 \\
(0.0371)\end{array}$ \\
\hline Indonesia & $\begin{array}{l}-0.0051 \\
(0.0279)\end{array}$ & $\begin{array}{l}-0.0342 \\
(0.0299)\end{array}$ & $\begin{array}{l}-0.0337 \\
(0.0299)\end{array}$ & $\begin{array}{l}-0.0067 \\
(0.0303)\end{array}$ \\
\hline Jordan & $\begin{array}{c}0.0017 \\
(0.0279)\end{array}$ & $\begin{array}{l}-0.0275 \\
(0.0299)\end{array}$ & $\begin{array}{l}-0.0269 \\
(0.0299)\end{array}$ & $\begin{array}{c}0.0001 \\
(0.0303)\end{array}$ \\
\hline Kuwait & $\begin{array}{c}0.0301 \\
(0.0902)\end{array}$ & $\begin{array}{c}0.0031 \\
(0.0907)\end{array}$ & $\begin{array}{c}0.0015 \\
(0.0907)\end{array}$ & $\begin{array}{c}0.0286 \\
(0.0908)\end{array}$ \\
\hline Malaysia & $\begin{array}{c}0.0033 \\
(0.0279)\end{array}$ & $\begin{array}{l}-0.0258 \\
(0.0299)\end{array}$ & $\begin{array}{l}-0.0253 \\
(0.0299)\end{array}$ & $\begin{array}{c}0.0017 \\
(0.0303)\end{array}$ \\
\hline Morocco & $\begin{array}{c}0.0272 \\
(0.0352)\end{array}$ & $\begin{array}{l}-0.0018 \\
(0.0367)\end{array}$ & $\begin{array}{l}-0.0014 \\
(0.0367)\end{array}$ & $\begin{array}{c}0.0256 \\
(0.0371)\end{array}$ \\
\hline Oman & $\begin{array}{l}-0.0142 \\
(0.0902)\end{array}$ & $\begin{array}{l}-0.0412 \\
(0.0907)\end{array}$ & $\begin{array}{l}-0.0427 \\
(0.0907)\end{array}$ & $\begin{array}{l}-0.0157 \\
(0.0908)\end{array}$ \\
\hline Pakistan & $\begin{array}{l}-0.0154 \\
(0.0326)\end{array}$ & $\begin{array}{l}-0.0444 \\
(0.0342)\end{array}$ & $\begin{array}{l}-0.0439 \\
(0.0342)\end{array}$ & $\begin{array}{l}-0.0169 \\
(0.0346)\end{array}$ \\
\hline Qatar & $\begin{array}{l}-0.0976 \\
(0.0902)\end{array}$ & $\begin{array}{l}-0.1247 \\
(0.0907)\end{array}$ & $\begin{array}{l}-0.1262 \\
(0.0907)\end{array}$ & $\begin{array}{l}-0.0991 \\
(0.0908)\end{array}$ \\
\hline Saudi Arabia & $\begin{array}{l}-0.2092^{* *} \\
(0.0902)\end{array}$ & $\begin{array}{l}-0.2363^{* * *} \\
(0.0907)\end{array}$ & $\begin{array}{l}-0.2378^{* * *} \\
(0.0907)\end{array}$ & $\begin{array}{l}-0.2108^{* *} \\
(0.0908)\end{array}$ \\
\hline Tunisia & $\begin{array}{c}0.0373 \\
(0.0722)\end{array}$ & $\begin{array}{c}0.0094 \\
(0.0729)\end{array}$ & $\begin{array}{c}0.0089 \\
(0.0729)\end{array}$ & $\begin{array}{c}0.0359 \\
(0.0731)\end{array}$ \\
\hline
\end{tabular}




\begin{tabular}{lclll} 
Turkey & 0.0369 & 0.0080 & 0.0084 & 0.0354 \\
& $(0.0352)$ & $(0.0367)$ & $(0.0367)$ & $(0.0371)$ \\
United Arab Emirates & $-0.1572^{*}$ & $-0.1842^{* *}$ & $-0.1857^{* *}$ & $-0.1587^{*}$ \\
& $(0.0902)$ & $(0.0907)$ & $(0.0907)$ & $(0.0908)$ \\
\hline R-square & 0.0181 & 0.0183 & 0.0185 & 0.0193 \\
\hline
\end{tabular}


Table 7

\section{Comparing Muslim and Non-Muslim Countries: Seemingly Unrelated Regressions}

All of the countries for which $\mathrm{MSCl}$ index data was available were divided into three groups depending on the proportion of population professing the Muslim faith. Group A comprises 14 nations in which Muslims constitute a majority; Group B includes 14 countries where the fraction of Islam adherents in the society falls between 5\% and 50\%; and Group C consists of 39 nations in which this fraction is below $5 \%$. Within each of the groups, a portfolio was constructed by equally weighting the dollar-denominated returns on the national $\mathrm{MSCl}$ indices. The daily returns on the resultant three portfolios were simultaneously regressed on a range of explanatory variables using the Seemingly Unrelated Regression (SUR) methodology. Ramadan is a dichotomous variable for the Muslim holy month defined here according to the motions of the moon observed from the perspective of Makkah. Halloween takes the value of 1 during the November-April period and 0 otherwise. January and Monday are indicator variables for the first month of the year and first day of the week, respectively. Return_World is the continuously compounded return on the valueweighted $\mathrm{MSCl}$ World Index. Coefficient standard errors are reported in parentheses. ${ }^{* * *},{ }^{* *},{ }^{*}$ denote statistical significance at $1 \%, 5 \%$ and $10 \%$, respectively.

Panel A. Influence of Ramadan in Three Different Groups of Countries

\begin{tabular}{lccc}
\hline & Group A & Group B & Group C \\
\hline Intercept & 0.0046 & $0.0158^{* *}$ & $0.0125^{* *}$ \\
& $(0.0062)$ & $(0.0067)$ & $(0.0062)$ \\
Ramadan & $0.0594^{* * *}$ & 0.0170 & 0.0301 \\
& $(0.0211)$ & $(0.0229)$ & $(0.0212)$ \\
Return_World & $0.0879^{* * *}$ & $0.3230^{* * *}$ & $0.5785^{* * *}$ \\
& $(0.0077)$ & $(0.0083)$ & $(0.0077)$ \\
Return_World_Lag & $0.1090^{* * *}$ & $0.1712^{* * *}$ & $0.1912^{* * *}$ \\
& $(0.0077)$ & $(0.0083)$ & $(0.0077)$ \\
\hline System Weighted R-square & & 0.3344 & \\
\hline
\end{tabular}

Panel B. Influence of Ramadan after Controlling for Other Seasonal Anomalies

\begin{tabular}{lccc}
\hline & Group A & Group B & Group C \\
\hline Intercept & 0.0074 & 0.0095 & 0.0086 \\
& $(0.0088)$ & $(0.0096)$ & $(0.0089)$ \\
Ramadan & $0.0519^{* *}$ & 0.0077 & 0.0212 \\
& $(0.0214)$ & $(0.0233)$ & $(0.0215)$ \\
Halloween & 0.0127 & $0.0246^{*}$ & $0.0211^{*}$ \\
& $(0.0127)$ & $(0.0138)$ & $(0.0127)$
\end{tabular}




\begin{tabular}{lccc} 
January & $0.0566^{* *}$ & 0.0160 & 0.0311 \\
Monday & $(0.0222)$ & $(0.0242)$ & $(0.0223)$ \\
& $-0.0664^{* * *}$ & $-0.0320^{* *}$ & $-0.0419^{* * *}$ \\
Return_World & $(0.0148)$ & $(0.0161)$ & $(0.0149)$ \\
& $0.0875^{* * *}$ & $0.3226^{* * *}$ & $0.5780^{* * *}$ \\
Return_World_Lag & $(0.0076)$ & $(0.0083)$ & $(0.0077)$ \\
& $0.1091^{* * *}$ & $0.1710^{* * *}$ & $0.1911^{* * *}$ \\
\hline System Weighted R-square & $(0.0076)$ & $(0.0083)$ & $(0.0077)$ \\
\hline
\end{tabular}

